\title{
Seismic safety assessment of existing masonry infill structures in Nepal
}

\author{
Hemchandra Chaulagain $^{1 \dagger}$, Hugo Rodrigues ${ }^{2 \ddagger}$, Enrico Spacone ${ }^{3 \S}$ and Humberto Varum ${ }^{4 \S}$ \\ 1. Civil Engineering Department, University of Aveiro, 3810-193 Aveiro, Portugal \\ 2. RISCO, School of Technology and Management, Polytechnic Institute of Leiria, Leiria, Portugal \\ 3. University of Chieti-Pescara, Department PRICOS - Architettura, 65127 Pescara, Italy \\ 4. CONSTRUCT-LESE, Faculty of Engineering (FEUP), University of Porto, Portugal
}

\begin{abstract}
Reinforced concrete (RC) buildings in Nepal are constructed with RC frames and masonry infill panels. These structures exhibit a highly non-linear inelastic behavior resulting from the interaction between the panels and frames. This paper presents an extensive case study of existing RC buildings in Nepal. Non-linear analyses were performed on structural models of the buildings considered as a bare frame and with masonry infill, in order to evaluate the influence of infill walls on the failure mechanisms. Five three-storey buildings with different structural configurations and detailing were selected. The effect of masonry infill panels on structural response was delineated by comparing the bare-framed response with the infill response. Seismic performance is evaluated with regard to global strength, stiffness, energy dissipation, inter-storey drift, and total deflection of the structure. A parametric analysis of structures with masonry infill is also performed. For this, the influence of different material properties is studied, namely diagonal compressive stress, modulus of elasticity and tensile stress of masonry infill panels. Study results show that masonry infill increases the global strength and stiffness of the structures; it decreases the inter-storey drift and hence the total displacement of the structure. The results quantify the influence of the infill panels on structural response and, in particular, the effect of the diagonal compressive strength of the masonry wall.
\end{abstract}

Keywords: RC buildings; non-linear analysis; masonry infill wall; seismic assessment; sensitivity analysis

\section{Introduction}

Reinforced concrete frame structures with masonry infill are extensively used in urban areas of Nepal. In rural areas most of the buildings are built with adobe, brick with mud mortar, brick with cement mortar, stone with mud mortar, stone with cement mortar and wood (JICA, 2002). Brick masonry is the most common infill material in Nepal because of its abundance, low cost, good sound and heat insulation properties, and the availability of skilled labor in this construction technique. Masonry panels are usually built up after the frames and floor structures have been constructed. There is a lack of structural design standards for masonry infill walls since they are normally treated as non-structural components. However, they will interact with the surrounding frame in the event of an earthquake. The construction of frame and masonry infill in different

\footnotetext{
Correspondence to: Hugo Rodrigues, Civil Engineering Department, School of Technology and Management, Polytechnic Institute of Leiria, Leiria, Portugal

Tel: +351965797364

E-mail: hugo.f.rodrigues@ipleiria.pt

${ }^{\dagger} \mathrm{PhD} ;{ }^{\ddagger}$ Assistant Professor; ${ }^{\S}$ Full Professor
}

Received November 25, 2014; Accepted September 14, 2015 ways, especially due to their difference in stiffness, causes complex behavior during seismic excitation. The ability to assess the seismic performance of these structures is of great importance from the point of view of seismic risk mitigation and human safety.

$\mathrm{RC}$ buildings are normally designed and analyzed as a bare frame without considering the contribution of the infill material to strength and stiffness. However, during earthquakes, infill walls modify the response of the structure which is different from that of the bare frame. Significant experimental and analytical research has been reported in the literature on the beneficial as well as ill effects of infill walls (Dhaneseka and Page, 1986; Crisafulli, 1997). Much of the research has concluded that infill walls increase the global strength, stiffness, damping, and energy dissipation capacity of structures. Infill decreases the inter-storey drift and hence the total deflection of the structure (Varum, 2003; Rodrigues et al., 2010). The pushover curve of an infill frame can be quite different from that of the corresponding bare frame. The presence of infill panels modifies the typical elasticperfectly plastic response curve by giving it a higher peak strength and a descending branch enclosed within a short displacement range (Dolsek and Fajfar, 2005). However, infill can also have some ill effects on the building such as 'soft storey', short-column effect, and 
torsion. The behavior of the infill is highly dependent on the quality of material, workmanship, and frame-infill interface. Thus, modeling infill frames is a complex process because these structures exhibit a highly nonlinear inelastic behavior resulting from the interaction of the masonry infill panel and the surrounding frame.

In this context, the present study is an extensive case study/analysis of existing RC framed buildings in a highly seismically active region of Nepal (see Fig. 1). Non-linear analyses were performed on structural models of each of the buildings, both as a bare-framed structure and with infill, in order to evaluate the influence of infill walls on the failure mechanisms. For this, five threestorey buildings with different structural configurations and details were selected for analysis. The effect of masonry infill on the response of structures is quantified by comparing the frame-infill response with the frameonly response. The seismic performance evaluation assessed global strength, stiffness, energy dissipation, inter-storey drift, and total displacement of structures. Furthermore, a parametric analysis of RC structures with masonry infill is performed and the influence of various parameters, viz., diagonal compressive stress, modulus of elasticity and tensile stress of masonry infill, quantified.

\section{RC buildings with masonry infill in Nepal and standard recommendations}

\subsection{Influence of masonry infill panel on RC framed structure}

History reveals the occurrence of a large earthquake every 60-70 years in Nepal and the history of construction practices of RC buildings is only 30-40 years old (UNDP, 1994). With such a short history, these structures have very limited or negligible experience of damage in past earthquakes. Nepal can however, learn important lessons from past earthquakes in India, Pakistan, Indonesia and Turkey since the building construction trends, practices and seismic hazard level of these countries are similar to those of Nepal. Experience of damage to buildings in past earthquakes indicate that masonry infill can drastically modify the structural response from anticipated, attracting forces to parts of the structure not designed to resist them (Paulay and Priestley, 1992). The contribution of infill to the building response can be positive or negative, depending on the underlying phenomena and parameters such as, for example, relative stiffness and strength between the frames and the masonry walls (Mainstone, 1971).

Common failure modes in masonry panels observed in past earthquakes in India, Pakistan, Turkey, and Indonesia are presented in Figs. 2 and 3. As indicated in the figures, during earthquakes, there may be a change in the out-of-plane tilting infill panel, out of plane failure of infill wall, and diagonal failures. In certain situations, short-column mechanism may occur in a building when the RC frame bay is partially filled with brick masonry, leaving wide openings for windows; during an earthquake large concentrations of stresses may occur at the corners of the openings. However, sometimes infill can protect the structure from failure (Vicente et al., 2012). In Fig. 3(c), the building is supported by infill walls even after the column has failed.

\subsection{Use of masonry infill in common RC buildings in Nepal}

Most of the RC building construction in Nepal is based on RC frames with masonry infill walls. Infill walls are constructed either floor-by-floor immediately after construction of RC structures at each floor or after the completion of whole frame structure. Most of these buildings have between two and six storeys, but the

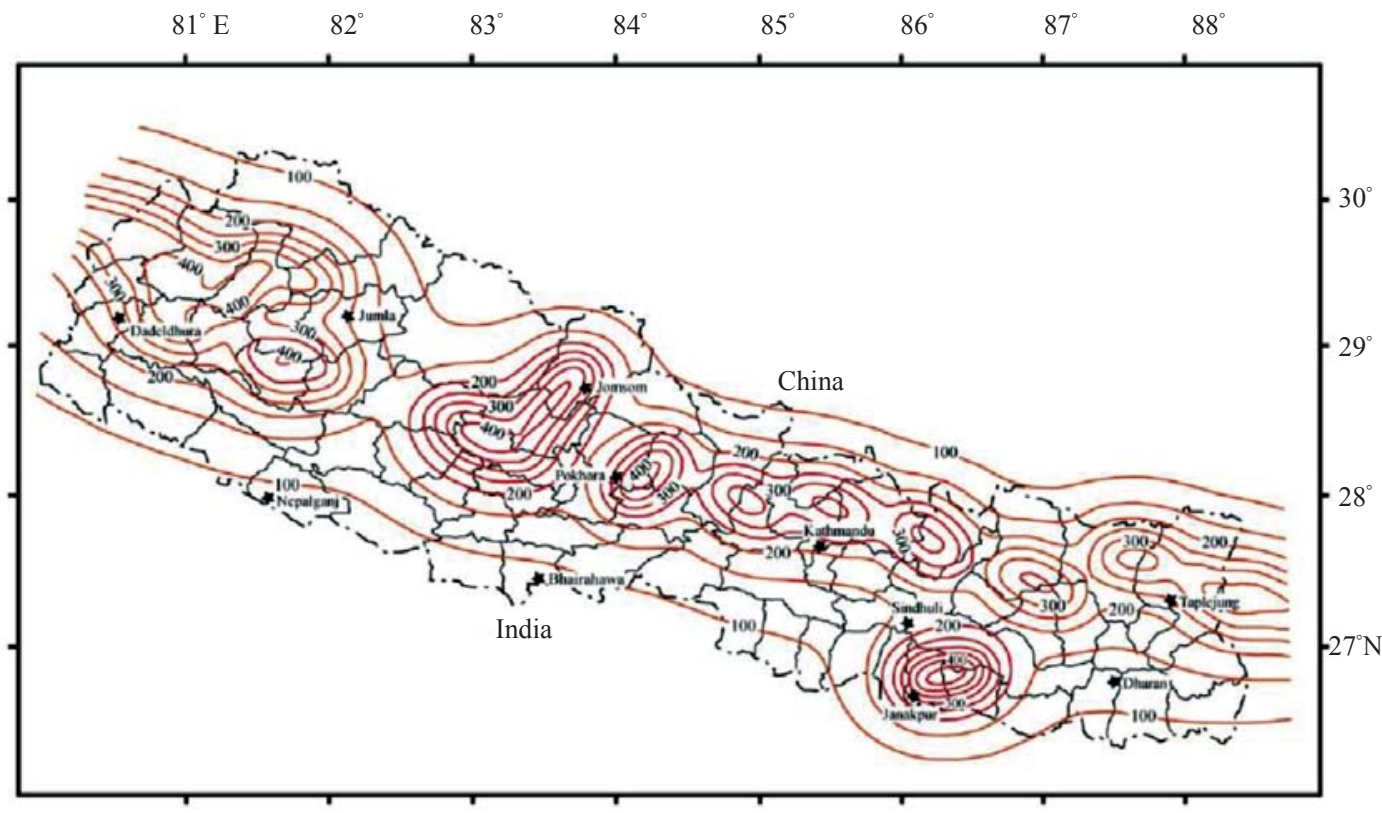

Fig. 1 Seismic hazard map of Nepal (Pandey et al., 2002) 
majority of them are three storeys. In most buildings the exterior walls and the walls adjacent to staircases are $230 \mathrm{~mm}$ (one brick) thick and other internal partition walls are $115 \mathrm{~mm}$ (half brick) thick. The rear side of the building consists of a full brick wall while the remaining three sides have door and window openings. The RC building construction process and existing building structures in Nepal are presented in Figs. 4 and 5.

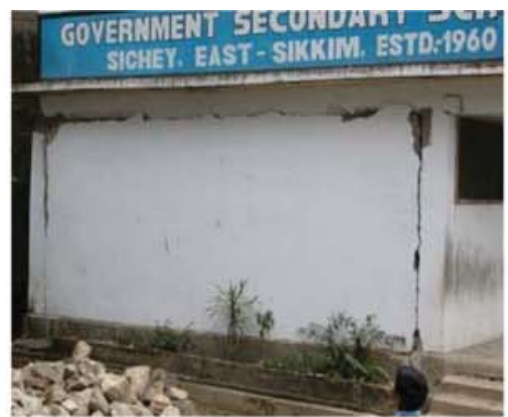

(a)

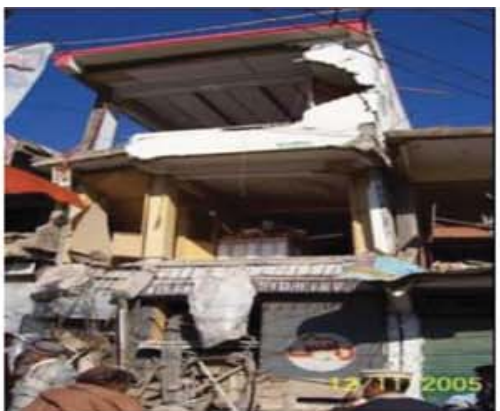

(b)

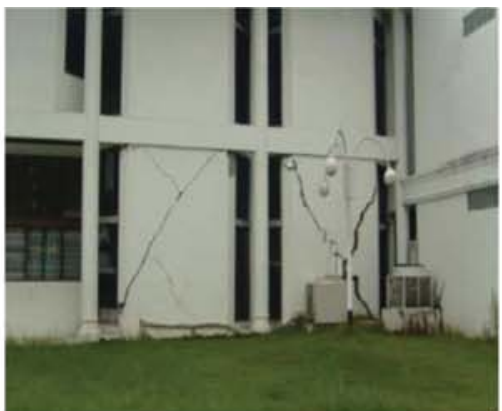

(c)

Fig. 2 Damage to masonry infill walls: (a) out-of-plane tilting of masonry infill wall, India; (b) out-of-plane failure of infill walls, Pakistan; (c) diagonal failure of infill walls separated from columns, Indonesia (Bothara and Hicyilmaz, 2008)
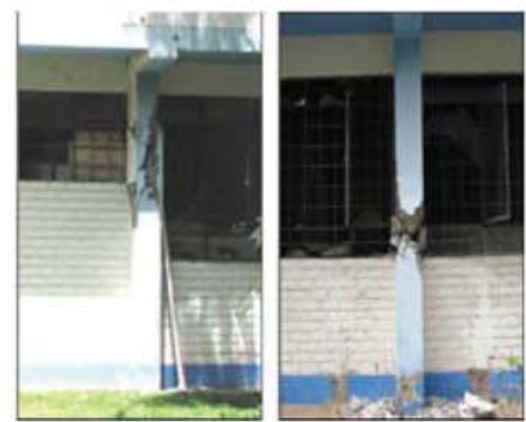

(a)

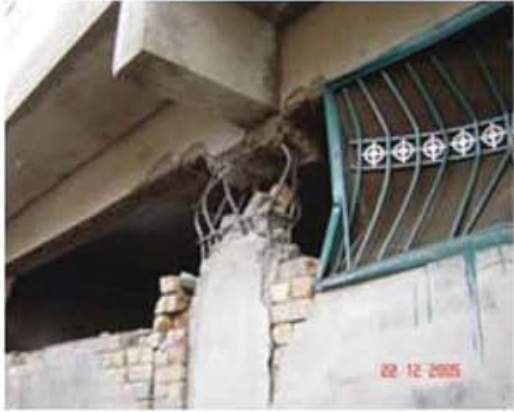

(b)

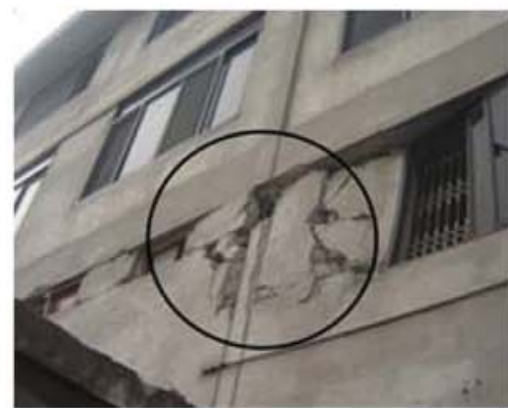

(c)

Fig. 3 Effects of masonry infill wall on structure: (a) and (b) short-column mechanism in Turkey; (c) building being supported by infill walls after failure of column, Pakistan (Dogangun, 2004)

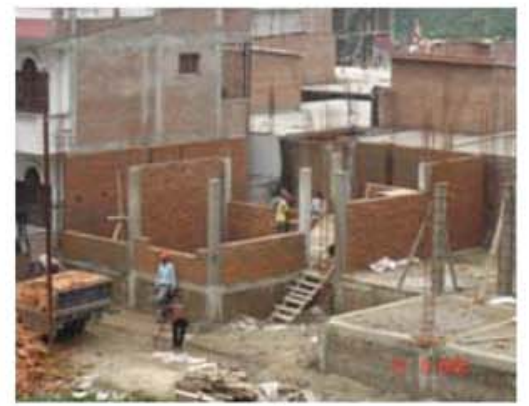

(a)

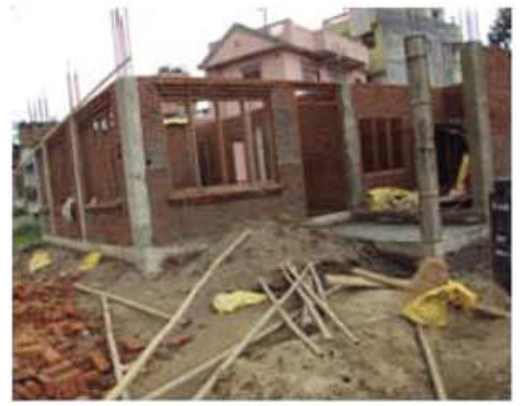

(b)

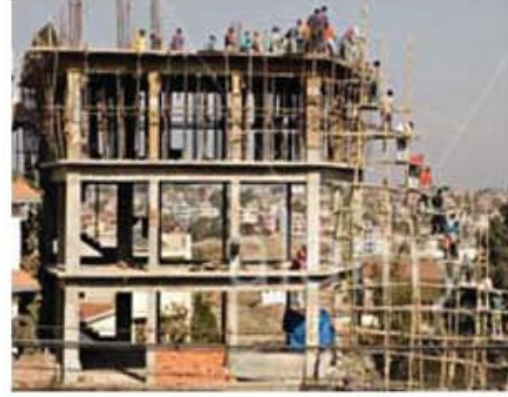

(c)

Fig. 4 RC building construction process: (a) and (b) infill walls are constructed floor-by-floor immediately after construction of RC structure at each floor; (c) the construction of whole structure precedes infill construction

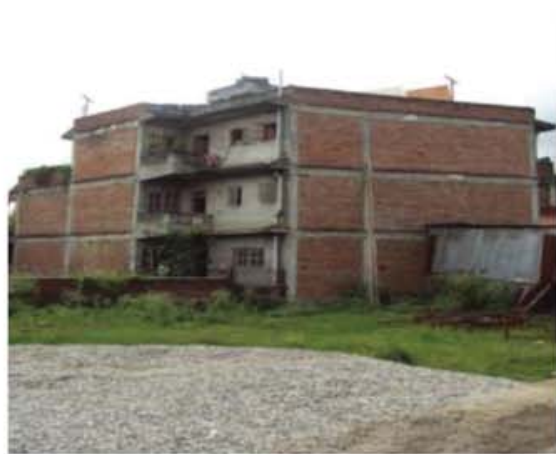

(a)

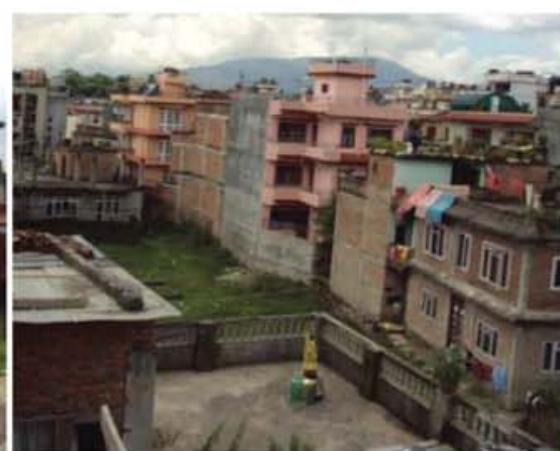

(b)

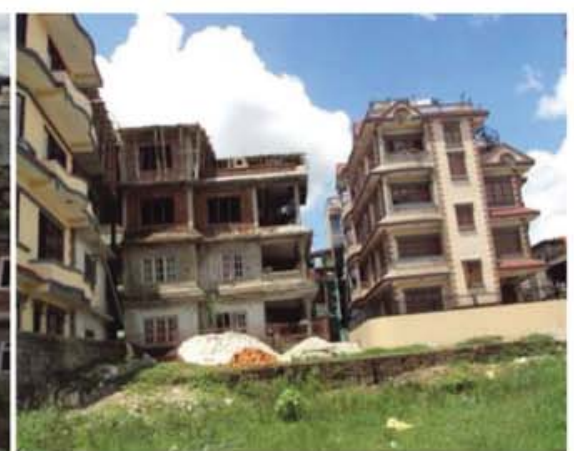

(c)

Fig. 5 Existing infill masonry building structures in Nepal 


\subsection{Standard recommendations}

RC framed buildings with masonry infill walls are usually analysed and designed as bare frames, without considering the contribution of the infill walls to strength and stiffness. However, during earthquakes, these infill walls contribute to the response of the structure and the behaviour of a filled frame is different from that predicted for bare framed structures. Different codes and guidelines have been proposed on how to incorporate the infill wall into the design/construction of the moment resisting frame.

Nepal Building Code (NBC 205, 1994) provides some provisions in terms of dimensions and details for up to three-storey RC framed buildings. Likewise, the Indian standards code recommends linear elastic analysis of the bare frame structure excluding the effect of brick infill (IS 1893, 2002). Eurocode 8 treats brick masonry in-filled RC frames as 'dual' systems, which are classified into three ductility classes; high, medium and low (Eurocode 8, 2004). EC8 specifies that the period of a structure to be used to evaluate the seismic base shear shall be the average of that for the bare frame and for the elastic infill frame. Frame member demands are then determined by modelling the frame structure without the infill. The international guidelines FEMA-273 (1997) and FEMA-356 (2000) include a procedure to assess the structural response of buildings, considering infills. As per these documents, masonry infill panels shall be represented by the equivalent diagonal struts. The struts may be placed concentrically across the diagonals, or eccentrically to evaluate the effect of infill on the columns directly. The shear behaviour of masonry infill panels is considered as a deformation control action.

\subsection{Limit states for different moment resisting frame structures}

The definition of limit states for structures with and without masonry infill walls can be directly related to the inter-storey drift demand. The selection of the appropriate drift associated with different levels of damage for the design is significant in terms of cost and safety of the structures; the identification of drift levels associated with different states of damage remains one of the unsolved issues in the development of performance objectives. However, researchers have proposed different limit states for assessing the performance of the structures. Magenes and Pampanin (2004) proposed an empirical relationship for the damage level of a masonry infill panel corresponding to a certain limit state, based on the axial deformation. For example, an inter-storey drift value in the range of $0.4 \%-1.0 \%$ can be associated with the failure of the infill panel. The FEMA-306 (1997) and FEMA-307 (1999) documents also provide reference values of inter-storey drift ratios for RC buildings with masonry infill panels. The drift limits proposed differ with the type of masonry, from $1.5 \%$ for brick masonry to $2.5 \%$ for un-grouted concrete block masonry. These documents also indicate a drift reference value of $0.25 \%$ for the initiation of diagonal cracking (Bell and Davidson, 2001). Drifts around $0.2 \%$ are recommended for brick masonry infills in contact with the surrounding frame, whereas $0.5 \%$ is more appropriate for plywood, plaster, gypsum, and similar lightweight panels (Freeman, 1977). FEMA-356 (2000) proposed the limit of $0.2 \%$ drift for fully operational, $0.5 \%$ for operational, $1.5 \%$ for life safety (extensive damage), and $2.5 \%$ for near collapse. However, Ghobarah (2004) proposed drift limit for both ductile, non-ductile moment resisting frames (MRF) and MRFs with infill. The maximum drifts associated with various damage levels is presented in Table 1 and these criteria will be used for the present assessment.

\section{Description of the studied building structures}

Five existing RC moment-resisting frame (RC-MRF) structures with and without masonry infill walls are selected for analysis. All these building configurations are typical of seismically active regions, where the vast majority of dwellings are RC buildings with similar structural characteristics (Chaulagain et al., 2014). The first two of the buildings studied are representative of non-engineered construction, namely: (a) NRCB1 and (b) NRCB2. The third and fourth are engineered RCMRF constructions, denoted as: (c) NRCB3 and (d) NRCB4. The remaining building is a well designed structure, denoted as NRCB5. Non-engineered buildings (mostly owner built construction) are those constructed without technical advice; these buildings are usually built informally without following specific engineering guidelines. Engineered buildings are built according to standard engineering guidelines. Many of the newly constructed RC buildings in urban areas of Nepal are likely to be of this type (see Fig. 6). The well designed structure is constructed based on the standard seismic code, with ductile detailing appropriate for a

Table 1 Maximum drift limits (\%) associated with various damage levels (FEMA-356, 2000; Ghobarah, 2004)

\begin{tabular}{cccc}
\hline State of damage & Ductile MRF & Non-ductile MRF & MRF with infills \\
\hline Fully operational & 0.20 & 0.20 & 0.30 \\
Operational & 0.50 & 0.40 & 0.50 \\
Life safety & 1.50 & 1.00 & 0.70 \\
Near collapse & 2.50 & 1.50 & 1.50 \\
\hline
\end{tabular}




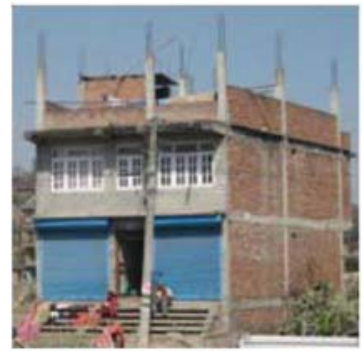

(a)

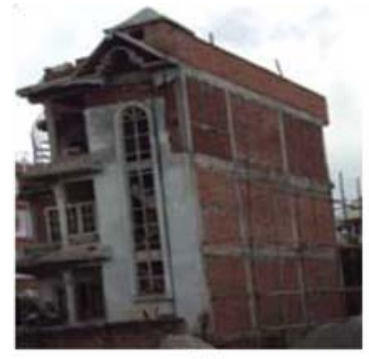

(b)

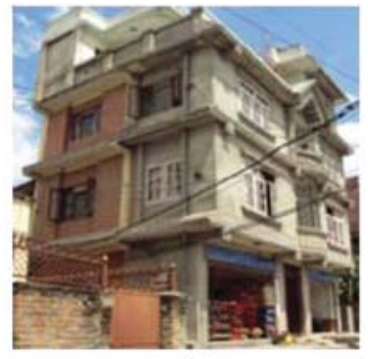

(c)

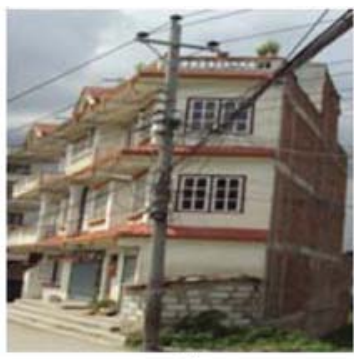

(d)

Fig. 6 Representative of non-engineered (a) \& (b) and engineered (c) \& (d) buildings in Nepal

building located in Seismic Zone V (shaking intensity of IX and higher) and medium soil type (IS1893:2002, IS 13920:1993).

The first two buildings are non-engineered $\mathrm{RC}$ MRF structures with square (NRCB1) and rectangular plan configuration (NRCB2), respectively, built in the southern part of Kathmandu valley. All buildings of this type have $3 \mathrm{~m}$ inter-storey height in all storeys. The NRCB1 model has 4 rooms per storey whereas NRCB2 has 6 . The NRCB1 building model is $9 \mathrm{~m} \times 9 \mathrm{~m}$ with three moment-resisting systems in both the $X$ and $Y$ directions. At the ground floor and first storey, the dimensions of all the columns are $23 \mathrm{~cm} \times 30 \mathrm{~cm}$ and all the beams are $23 \mathrm{~cm} \times 35 \mathrm{~cm}$ and at the top storey these dimensions are, respectively, $23 \mathrm{~cm} \times 23 \mathrm{~cm}$ and $23 \mathrm{~cm} \times 35 \mathrm{~cm}$. Likewise, in NRCB2, the lateral load resisting elements in the $X$ direction consist of three moment-resisting frames, and in $Y$-direction there are four such frames. The building dimension in plan is $10.5 \mathrm{~m} \times 8 \mathrm{~m}$. Furthermore, in non-engineered buildings 8 mm stirrups @200 mm c/c throughout the length of beam and columns were used where for engineered buildings 8 mm stirrups @,100 mm $\mathrm{c} / \mathrm{c}$ throughout the length of beam and columns were used.

The next two case-study buildings are engineered $\mathrm{RC}-\mathrm{MRF}$ structures with regular (NRCB3) and irregular plan configuration (NRCB4), both recently constructed in the northern part of the Kathmandu valley. The interstorey height of these buildings is $2.85 \mathrm{~m}$ in all storeys. Building NRCB3 has a plan area of $9.6 \mathrm{~m} \times 7.9 \mathrm{~m}$ $\left(75.84 \mathrm{~m}^{2}\right)$ measured from the column centre lines. Four identical moment-resisting frames in $X$ - and $Y$-directions act as lateral load resisting elements. Building NRCB4 has a trapezoidal plan area measuring $70.8 \mathrm{~m}^{2}$ which has three and four moment-resisting frames in $X$ - and $Y$-directions, respectively. Plan, 3-D view and cross sectional detailing of the non-engineered and engineered building models are presented in Figs. 7-10.

The well designed structure (NRCB5) has two and three bays of $3 \mathrm{~m}$ and $4 \mathrm{~m}$ in the $X$ and $Y$ directions, respectively. All floors have the same inter-storey height of $3 \mathrm{~m}$. Beams and columns are designed with the IS 13920:1993 (1993) recommendations. The dead loads considered are the self weight of the structural members (beams, columns and slabs) and partition walls according to IS 875 (Part I) (2003). The live load and
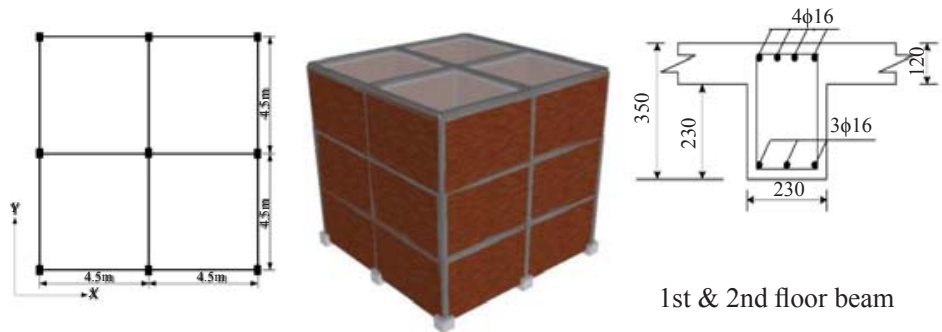

1 st \& 2nd floor beam
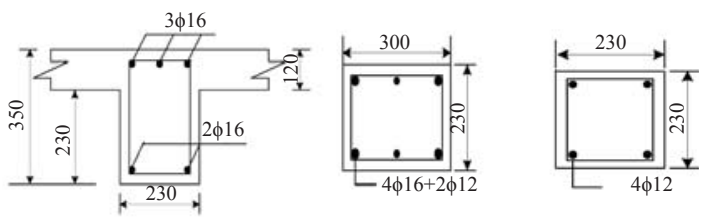

3rd floor beam

1 st \& 2nd storey column

Top storey

Fig. 7 Plan, 3-D view and cross-sectional detailing of building model NRCB1
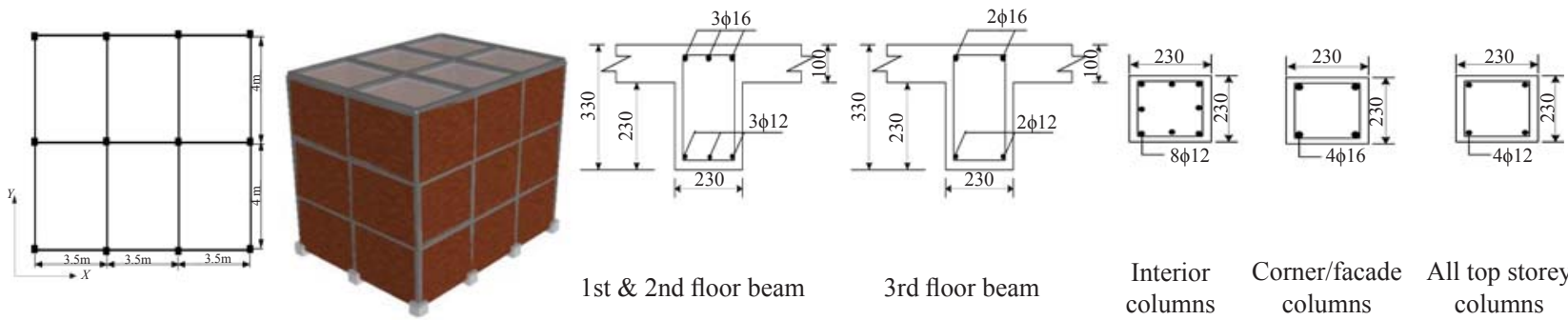

Fig. 8 Plan, 3-D view and cross-sectional detailing of building model NRCB2 
load combination is considered according to IS 4562000 (2000). Details of building model NRCB5 are presented in Fig. 11.

All aforementioned structures are typical threestorey residential buildings constructed in different locations in the Kathmandu valley. The arrangement of brick walls is as shown in Figs. 7-11. The grade of concrete used is M20 (characteristics strength of concrete $=20 \mathrm{~N} / \mathrm{mm}^{2}$ ) and the steel is Fe415 (yield strength of steel $=415 \mathrm{~N} / \mathrm{mm}^{2}$ ). For concrete, the modulus of elasticity is taken as that recommended by IS 456 , that is, $5700 f_{\mathrm{ck}} \mathrm{MPa}$, where $f_{\mathrm{ck}}$ is 28 -days characteristic cube
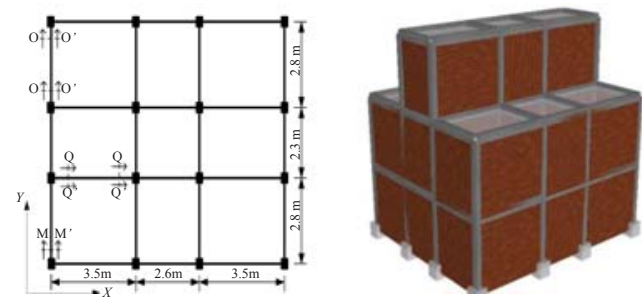
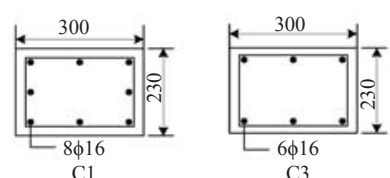

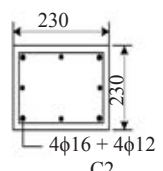

$\mathrm{C} 2$

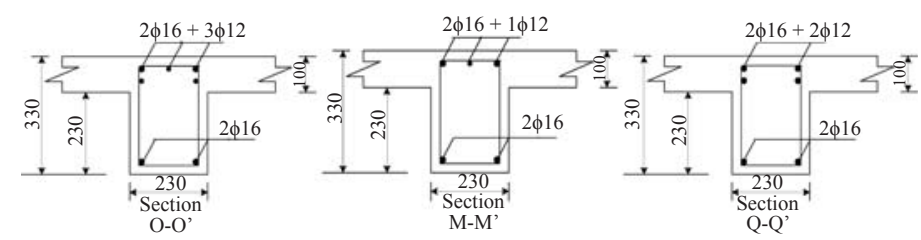

Fig. 9 Plan, 3-D view and cross-sectional detailing of building model NRCB3
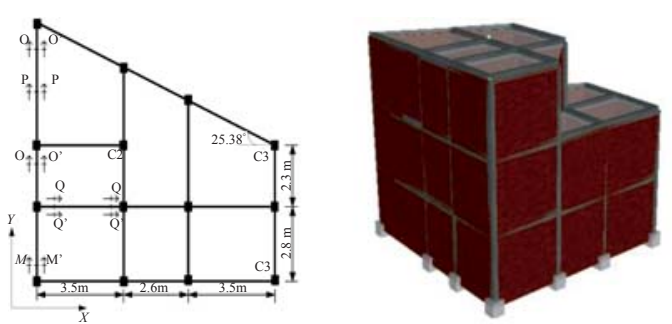

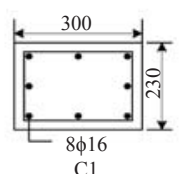

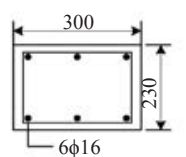

$\mathrm{C} 3$

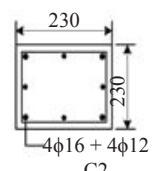

$\mathrm{C} 2$

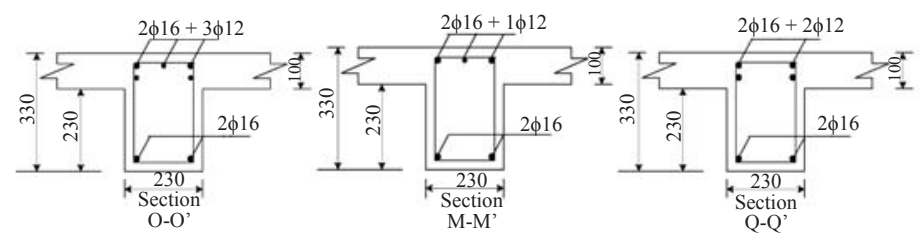

Fig. 10 Plan, 3-D view and cross-sectional detailing of building model NRCB4

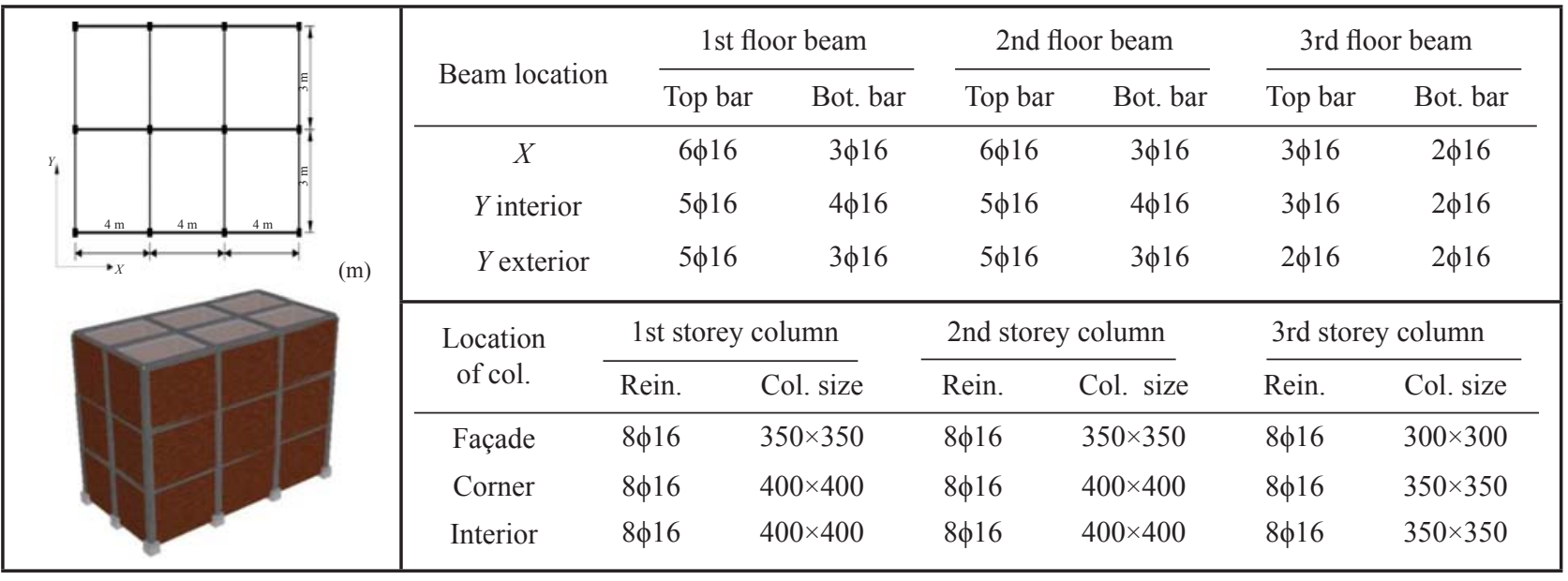

Fig. 11 Plan, 3-D view and cross-sectional detailing of building model NRCB5

Note: All dimensions are in mm unless stated otherwise;

Beam size of NRCB5 structure is $230 \mathrm{~mm} \times 325 \mathrm{~mm}$.

All the interior, façade and corner columns of building models NRCB3 and NRCB4 are C1, C2 and C3 respectively unless stated otherwise. 
strength. The Poisson's ratio and unit weights for the concrete are taken as 0.2 and $25 \mathrm{kN} / \mathrm{m}^{3}$, respectively. For brick masonry infill walls, the modulus of elasticity $\left(E_{\mathrm{m}}\right)$ and Poisson's ratio $(\mu)$ are taken as $2300 \mathrm{~N} / \mathrm{mm}^{2}$ and 0.15 , respectively. The diagonal compressive stress $\left(f_{\mathrm{m}}\right)$ and tensile stress of brick masonry wall are taken as 2.3 $\mathrm{N} / \mathrm{mm}^{2}$ and $0.575 \mathrm{~N} / \mathrm{mm}^{2}$, respectively. The masses of brick walls are distributed to all beams at floor levels. The external and internal brick walls are taken to be 230 $\mathrm{mm}$ and $115 \mathrm{~mm}$ thick, respectively. The floor finish on floors and the weathering course on the roof are taken as $1.0 \mathrm{kN} / \mathrm{m}^{2}$ and $2.25 \mathrm{kN} / \mathrm{m}^{2}$, respectively. The live load on floors and that on the roof are taken as $2.0 \mathrm{kN} / \mathrm{m}^{2}$ and $0.75 \mathrm{kN} / \mathrm{m}^{2}$, respectively.

\section{Numerical modeling}

In the present study numerical analyses of the structures were performed using SeismoStruct (SeismoSoft, 2006) computer program which is capable of predicting large displacement behavior of space frames under static or dynamic loading, taking into account both geometric nonlinearities and material inelasticity. The accuracy of this software in non-linear analysis of framed structures was evaluated against experimental results during the 'concrete column blind prediction contest, 2010' (UCSD, San Diego, USA) and '15 WCEE blind test challenge' (LNEC, Lisbon,
Portugal). Moreover, Rodrigues et al. (2011) and Smyrou et al. (2011) also performed non-linear analysis of the RC building models and compared their results with experiments. In both cases, results obtained from the SeismoStruct software correlated with experimental results.

In the present study, nonlinear analyses of the building models are performed with adaptive pushover and dynamic time history analyses. For the adaptive pushover analyses, a response spectrum provided in the Indian seismic code is used (IS 1893, 2002) because the Nepal building code does not possess sufficient data required for standard design consideration. Currently, most of the engineered buildings in Nepal were designed based on the Indian seismic code. Earthquake ground motion histories are important for dynamic analyses of the structures. Although many earthquakes have been reported in the history of Nepal, no accelerations have been recorded. Due to the lack of time history data in Nepal, the dynamic analyses in this study were performed with generated time history data. Three different artificially generated time history records for Nepal, with increasing peak ground acceleration (PGA) values ranging from $0.07 \mathrm{~g}$ to $0.51 \mathrm{~g}$, were used (Parajuli, 2009). For inelastic time history analyses these time history data were scaled for the intermediate values. Artificially generated PGA for various return periods are tabulated in Table 2 and presented in Fig. 12.

Table 2 Artificial time history records (Parajuli et al., 2008; Parajuli, 2009)

\begin{tabular}{cc}
\hline Return period (years) & Peak ground acceleration $\left(\mathrm{m} / \mathrm{s}^{2}\right)$ \\
\hline 98 & $0.07 \mathrm{~g}$ \\
475 & $0.40 \mathrm{~g}$ \\
975 & $0.51 \mathrm{~g}$ \\
\hline
\end{tabular}

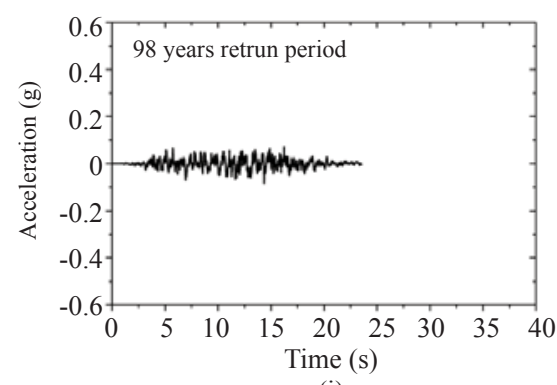

(i)

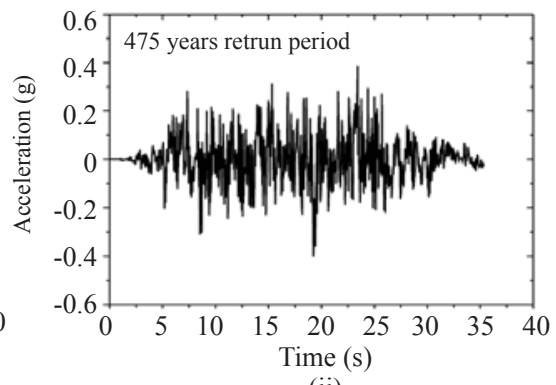

(ii)

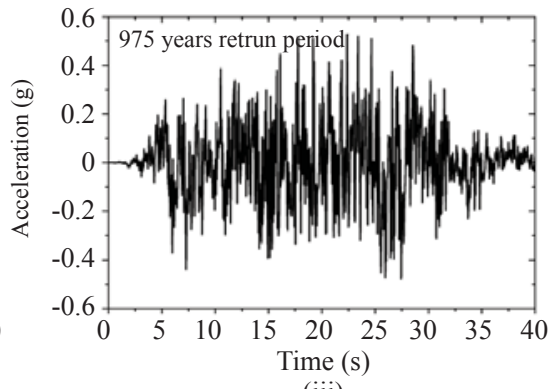

(iii)

(a) Time history data for: (i) 98 years, (ii) 475 years and (iii) 975 years return period

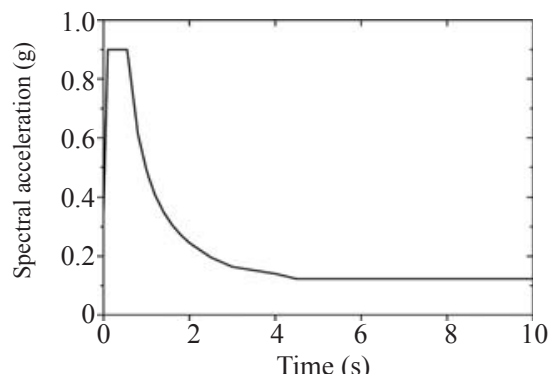

(b)

Fig. 12 (a) Time history; and (b) response spectrum used for numerical analysis of building models 


\subsection{Modelling of bare frame structures}

The computer program SeismoStruct (2006) was used, adopting a lumped plasticity model for the RC frame elements. The numerical analysis is based on bare frame building modelling with three-dimensional models. In the analyses performed in this paper, half of the larger dimensions of the cross-section is considered as the plastic hinge length with fibre discretisation at the section level.

The concrete model used is based on the Madas and Elnashai (1992) uniaxial model, which follows the constitutive law proposed by Mander et al. (1988). The cyclic rules included in the model are for confined and unconfined concrete in accordance with the Martinez-Rueda (1997) and Elnashai and Elghazouli (1993) proposals. The confinement effects provided by transverse reinforcement were considered through the rules proposed by Mander et al. (1988), whereby constant confining pressure is assumed throughout the entire stress-strain range, traduced by the increase in the peak value of the compression strength and the stiffness of the unloading branch.

The uniaxial model proposed by Menegotto and Pinto (1973), coupled with the isotropic hardening rules proposed by Filippou et al. (1983), was adopted for the reinforcement steel representation in these analyses. This steel model does not represent the yielding plateau characteristic of the mild steel virgin curve. The model takes into account the Bauschinger effect, which is relevant for the representation of the columns' stiffness degradation under cyclic loading. The model adopted in the analyses performed in this study is represented in Figs. 7-11.

\subsection{Modelling of infill panels}

Masonry infill panel is a composite constructional material of brick units and mortar joints. Due to the unique characteristics of individual materials, its material and geometrical properties can vary to a large extent in practical application. Nowadays, two finite element modelling techniques: a) micro-models (plane finite element) and b) macro-models (equivalent strut models) are adopted for numerical analysis of infill panels. The first group of models is based on continuum theory, providing relatively accurate computational representation of both material and geometrical aspects of masonry infill panels, but they are computationally extensive and difficult to apply for numerical analysis of large-scale structures. Macro models, on the other hand, use equivalent diagonal struts which are capable of describing the most common failure modes of masonry infill panels, which are of the most practical importance and of the greatest interest for engineers. The obvious advantage in terms of computational simplicity and efficiency makes the macro-models preferable for analyzing global responses of masonry in-filled frames with adequate precision.

As shown in Fig. 13(a), the infill panel is represented in the equivalent strut model by six strut members. Each diagonal direction features two parallel struts to carry axial loads across two opposite diagonal corners and a third one to carry the shear from the top to the bottom of the panel. This latter strut only acts across the diagonal that is under compression; hence its activation depends on the deformation of the panel. The axial load struts use the masonry strut hysteresis model, while the shear strut uses a dedicated bilinear hysteresis rule. The hysteresis
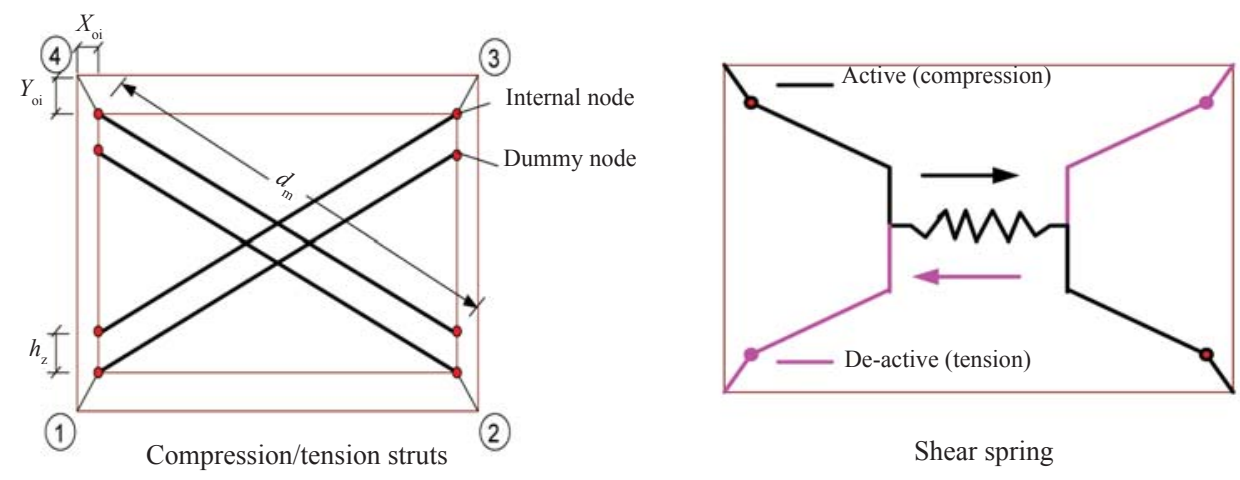

Shear spring

(a)

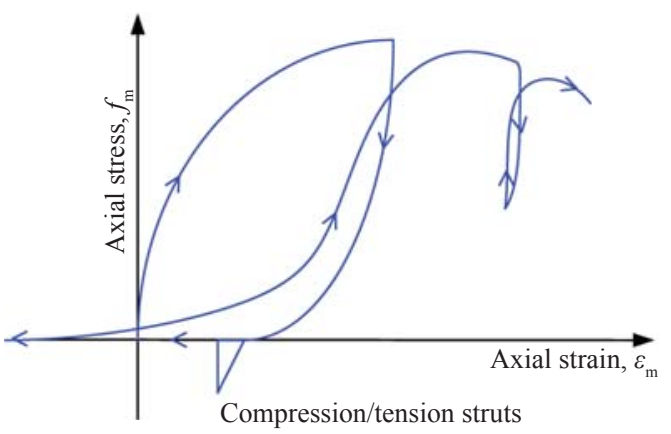

(b)

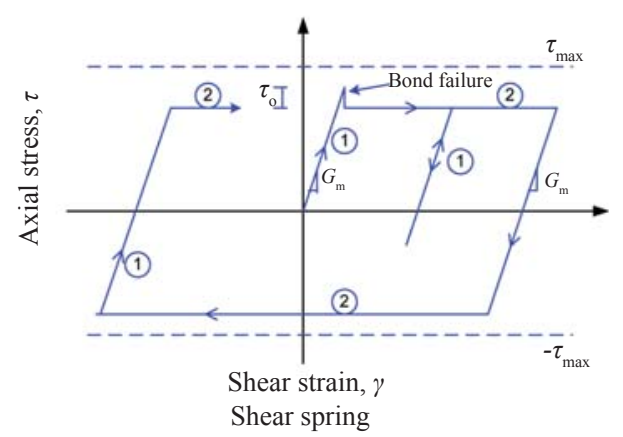

Fig. 13 Modeling of structures: (a) equivalent strut model; and (b) hysteretic rules for infill masonry wall (Crisafulli, 1997) 
rules for the two struts models are shown in Fig. 13(b) (Crisafulli, 1997; Smyrou et al., 2011). Also, as can be observed in Fig. 13(a) four internal nodes are employed to account for the actual points of contact between the frame and the infill panel (i.e., to account for the width and height of the columns and beams, respectively), whilst four dummy nodes are introduced with the objective of accounting for the contact length between the frame and the infill panel. All internal forces are transformed to the exterior four nodes, where the element is connected to the frame. The geometrical and mechanical properties of the strut members can be determined in terms of the geometrical parameters and material properties of the masonry infill panel.

In this study, the Seismostruct (2006) computer program is used for modelling the infill panels of the structures. It is based on a finite element package capable of predicting the large displacement behavior of frames under static or dynamic loading, considering both geometric non-linearities and material inelasticity. For numerical analyses of masonry panels, the finite element program of an advanced double-strut nonlinear cyclic model is used. The double-strut model is satisfactorily precise and less complicated than the single and triplestrut models, and can represent more accurately the local effect between infill and frame (Crisafulli, 1997). The idealization of an infill panel is based on the assumption that there is no bond between frame and infill. The brick masonry infill is modelled as a diagonal strut member whose thickness is the same as that of the masonry and whose length is equal to the diagonal length between compression corners of the frame. The effective width of the diagonal strut depends on various factors including; contact length, aspect ratio of the infill, and the relative stiffness of the frame and the infill. The effective width of the strut is calculated with the Paulay and Priestley (1992) approach. The infill panel openings are taken into account by reducing the value of strut area (i.e., the compression/tension strut cross-section) by a value that ranged between $30 \%$ and 50\% (Smyrou et al., 2011). These percentages are comparable with those proposed by Pinho and Elnashai (2000).

\section{Analysis and interpretation of results}

Results of the numerical analyses are presented in this section. The responses of structures with and without masonry infill panel are compared. Similarly, the effect of load pattern on seismic response of structures is addressed. For this capacity curves obtained from static pushover analysis with uniform and triangular load pattern is compared with adaptive pushover analysis. The influence of masonry infill on seismic response of structure is studied with capacity curve, inter-storey drift, energy dissipation, rotation, and global/local response of structure. Moreover, parametric analysis of the structures is performed to evaluate sensitivity to the properties of the infill panel. In the last sub-section, the vulnerability of the infill masonry structure is addressed.

\subsection{Natural frequencies}

The fundamental period is an inherent property of a structure and it depends on the building flexibility and mass of the structures. Masonry infill panels embedded in $\mathrm{RC}$ frames can influence the dynamic response of the structure to various degrees, according to their mechanical properties and geometrical distribution. In this study, eigen-value analysis is performed in order to determine the fundamental period of structures. The results indicate that the introduction of infill reduces drastically the period of vibration in all building models. Figure 14 indicates that first three modes are very important for performance evaluation of the buildings. Similarly, the period of vibration of buildings in $X, Y$ and rotation $(X Y)$ is presented in Table 3. It indicates that the fundamental period of vibration of NRCB1, NRCB3 and

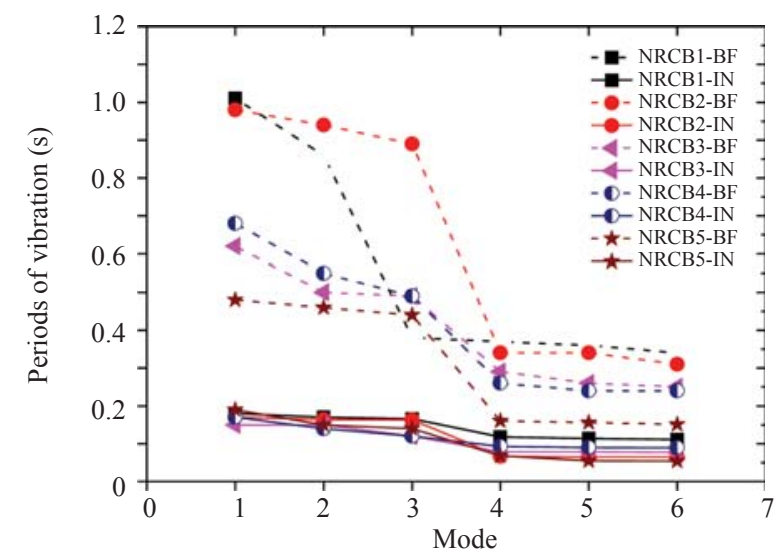

Fig. 14 Fundamental period of vibration for six vibration modes

Table 3 Time periods of case study building structures

\begin{tabular}{|c|c|c|c|c|c|c|}
\hline \multirow{3}{*}{ Building model } & \multicolumn{6}{|c|}{ Period of vibration } \\
\hline & \multicolumn{2}{|c|}{$X$-direction } & \multicolumn{2}{|c|}{$Y$-direction } & \multicolumn{2}{|c|}{$X Y$-rotation } \\
\hline & $\mathrm{BF}$ & IN & $\mathrm{BF}$ & IN & $\mathrm{BF}$ & IN \\
\hline NBCB1 & 1.010 & 0.180 & 0.868 & 0.176 & 0.381 & 0.166 \\
\hline NBCB2 & 0.944 & 0.164 & 0.980 & 0.171 & 0.897 & 0.163 \\
\hline NRCB3 & 0.625 & 0.151 & 0.494 & 0.150 & 0.502 & 0.126 \\
\hline NRCB4 & 0.686 & 0.169 & 0.555 & 0.141 & 0.496 & 0.128 \\
\hline NRCB5 & 0.464 & 0.191 & 0.484 & 0.151 & 0.444 & 0.142 \\
\hline
\end{tabular}


NRCB4 building models is along the $X$-direction (both IN and BF case). Stiffening is provided by the infills, indicated by a decrease in the fundamental periods of the structure. From the analysis of all the building models, it can be seen that dynamic characteristics directly affect the seismic response of the structures. Moreover, analysis indicates that structures associated with higher frequencies have better performance as compared to those with lower frequencies.

\subsection{Pushover analysis}

\subsubsection{Influence of load pattern on structural response}

In this study, the capacity curves obtained from static pushover analysis with uniform and triangular load patterns are compared with that from adaptive pushover analysis. The comparison of capacity curves for different pushover methods indicates that the strength and stiffness of a structure largely depend on the lateral force distribution. In bare frame structure (BF), the 'Uniform' distribution load pattern (U) generally leads to a pushover curve with higher elastic stiffness, higher yield strength, and lower yield displacement. The 'Triangular' distribution (T), on the other hand, leads to a pushover curve with lower elastic stiffness, lower yield strength, and higher yield displacement. The Adaptive Pushover (A) gives a pushover curve that is bounded by the pushover curves for uniform and triangular distributions. Briefly, in bare frame structures, uniform, adaptive, and triangular load patterns represent, respectively, an upper, intermediate and lower bound of the capacity curve in

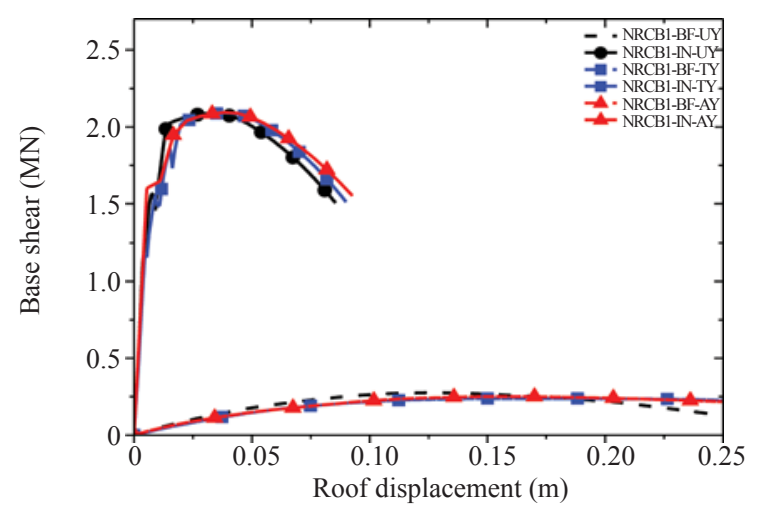

(a)

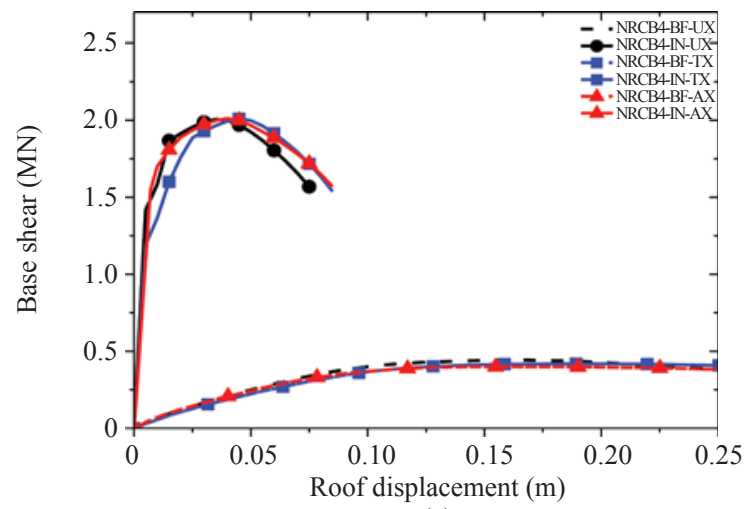

(c) the analysis cases. There is a consistency of results in all the bare frame buildings. However, in the case of masonry infill structures, the capacity curves vary. The same load pattern can lead to dissimilar capacity curves. Representative capacity curves from different load patterns for building models $1,2,3$ and 5 are presented in Fig. 15. Adaptive pushover analysis has the intermediate capacity curve which lies between those for uniform and triangular load patterns, for both bare frame (BF) and masonry infills (IN) structures. From these analyses it can be concluded that the intermediate outcomes may be considered the more reliable results. Therefore, the adaptive pushover analysis method is adopted in this study.

5.2.2 Seismic performance of structures with and without infill

The presence of infill panels increases the stiffness and strength of the system. This is confirmed by studying the pushover curves for bare frame and infill masonry structures. From Fig. 16, it can be observed that engineered buildings with masonry infill have a stiffness that is (4-12) times higher than that of the bare frame structure. Similarly, the stiffness is increased by more than 20 times for non-engineered building structure. However, the increase in stiffness is limited to (7.5-12) in well designed structure (NRCB5 building model). With regard to strength, it can be observed that masonry infill increases strength over the bare frame in engineered, non-engineered and well designed structures, by a factor of (3-4.5), (6.3-7.7), and (2.4-2.5), respectively.

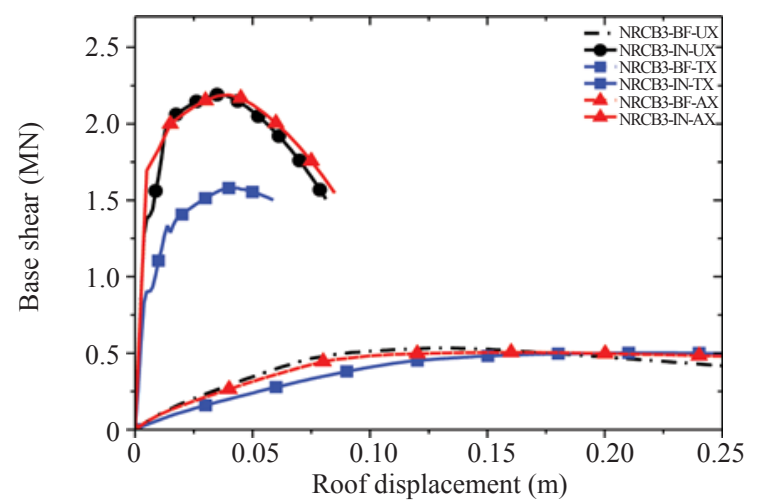

(b)

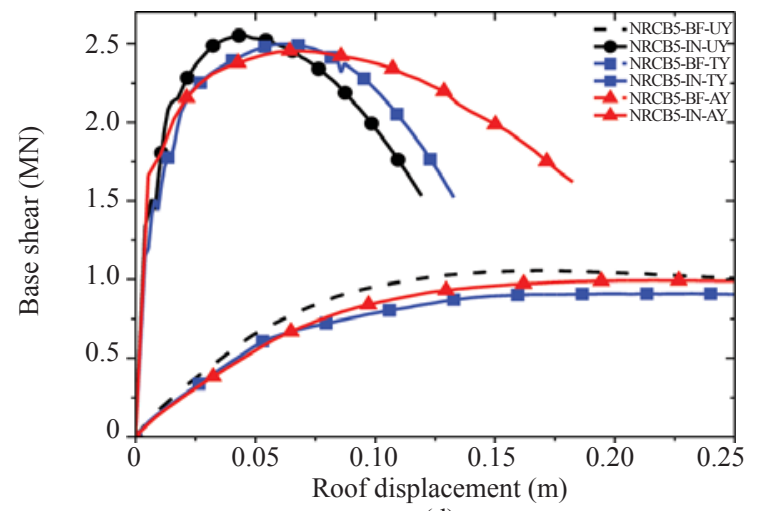

(d)

Fig. 15 Effect of load pattern on structure with and without considering the infill 
The allocation of various performance points on bare frame and masonry infill structures are based on the criteria discussed in Section 2.4. As shown in Fig. 16, the well designed, engineered and non-engineered structures with a bare frame (BF) have high, intermediate and poor performance levels, respectively. However, engineered and non-engineered structures with infill show similar behaviour. These structures do not have the distinct differences in performance point (IO, LS, CP and C) allocation. On the other hand, the well designed structure with infill shows an improved performance level. In fact, when a strong infill wall is in place the primary elements reach a crisis before the capacity of the panel is exhausted. The presence of masonry infill thus leads to a stiffer structure and enhanced capacity of the structure.

\subsection{Non-linear dynamic analysis}

To understand the complex interaction between masonry infill and reinforced concrete frames, certain structural parameters are studied with dynamic time history analysis. Dynamic time history analysis is a more refined method of analysis, used for obtaining seismic response of structures. In this subsection, the performance of the structure in terms of inter-storey drift (IS), total energy dissipation, global and storey level response, rotation, parametric analysis and seismic safety assessment is discussed.

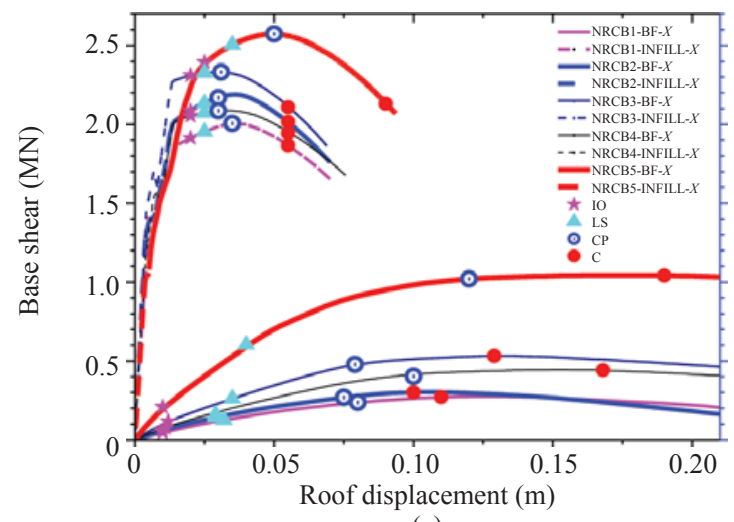

(a)

Fig. 16 Allocation of seismic performance point in capacity curves for: (a) $X$ and (b) $Y$ direction

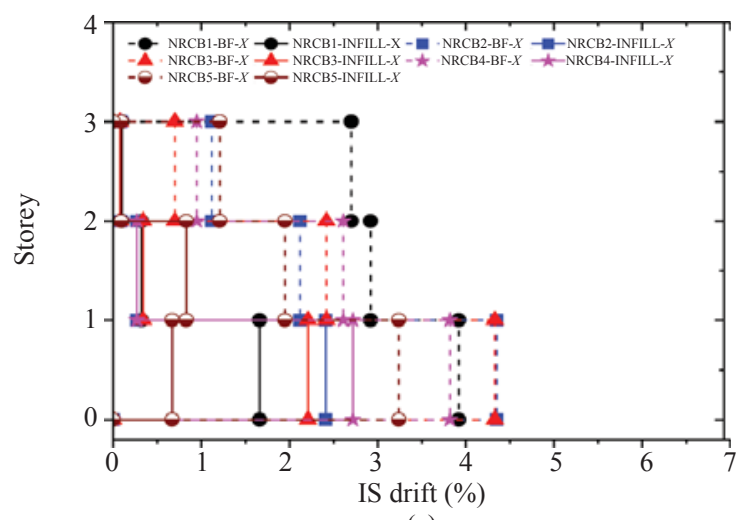

(a)

\subsubsection{Maximum inter-storey drift profiles}

The inter-storey (IS) drift for structures with and without infill panels is presented in Fig. 17. As indicated in the figure, there is a considerable reduction of IS drift due to the presence of infill masonry panels in both engineered and non-engineered buildings. In most of the cases, non-engineered buildings have surprising drift values at different floor levels. However, the introduction of masonry infill walls considerably reduces the IS drift, by more than half compared with bare frame structures. It is interesting to observe that, in the structures with infill, the responses of the ground and first storeys are quite different. In the ground storey, a regular behavior can be observed for all panels, whereas on the first storey the response is much more variable. It is due to the fact that the presence of infill panel induces an increase in the stiffness and strength of the system.

\subsubsection{Energy dissipation}

Energy dissipation capacity is an important indicator of the structure's ability to withstand severe ground motion. This parameter can be determined from the area enclosed by the hysteretic loops of the load-deformation relation. The total energy dissipation of the studied buildings is calculated by using dynamic time history analysis. As indicated in Fig. 18, the trends of energy dissipation for the buildings (both bare frame and infill masonry) are not uniform. In most of the cases bare frame structures have the higher energy dissipation capacity.

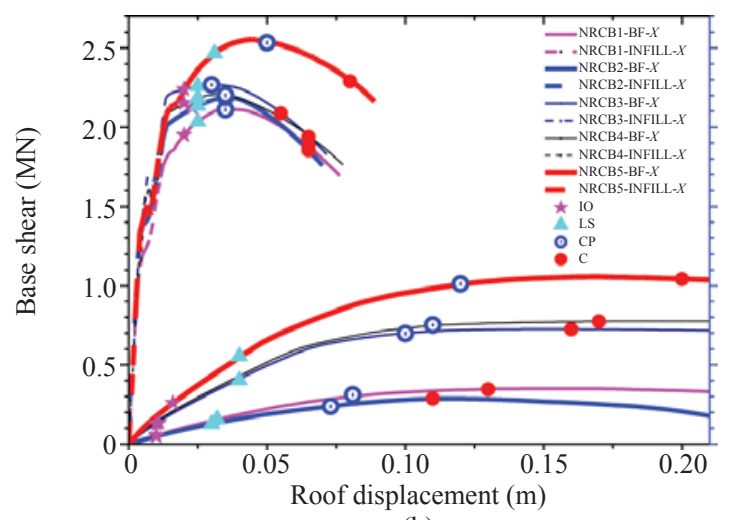

(b)

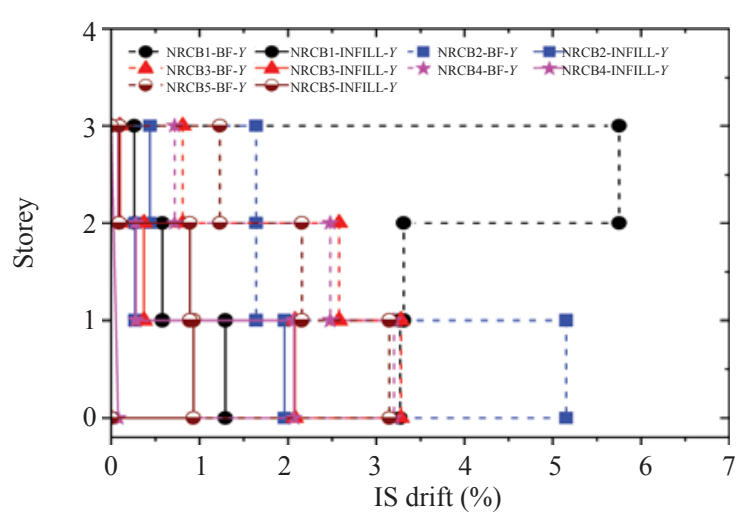

(b)

Fig. 17 Inter-storey drift profiles with and without masonry infill in (a) $X$ and (b) $Y$ direction 


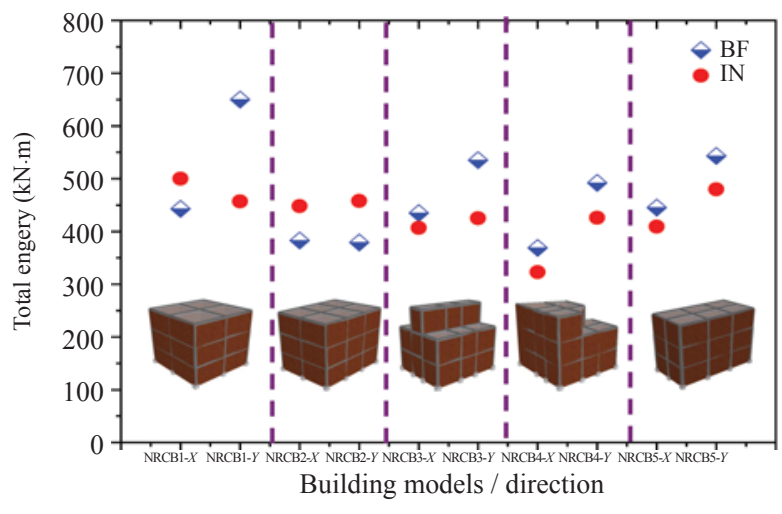

Fig. 18 Total energy dissipation of structures

However, in building Models 1 (in $X$ direction) and 2 (both $X$ and $Y$ directions), structures with masonry infill have higher energy dissipation capacity which may be due to the effect of light RC elements in these structures (mostly in the non-engineered structures).

\subsubsection{Global and local level response}

The global and local level response of the structure is studied through dynamic time history analysis. For global response the obtained result is plotted with base shear versus roof displacement whereas local level response is studied with ground-storey base shear vs. ground-storey drift. Results show that infill panels increase the global strength and stiffness of the structure. As expected nonengineered structure (NRCB1) has very low performance
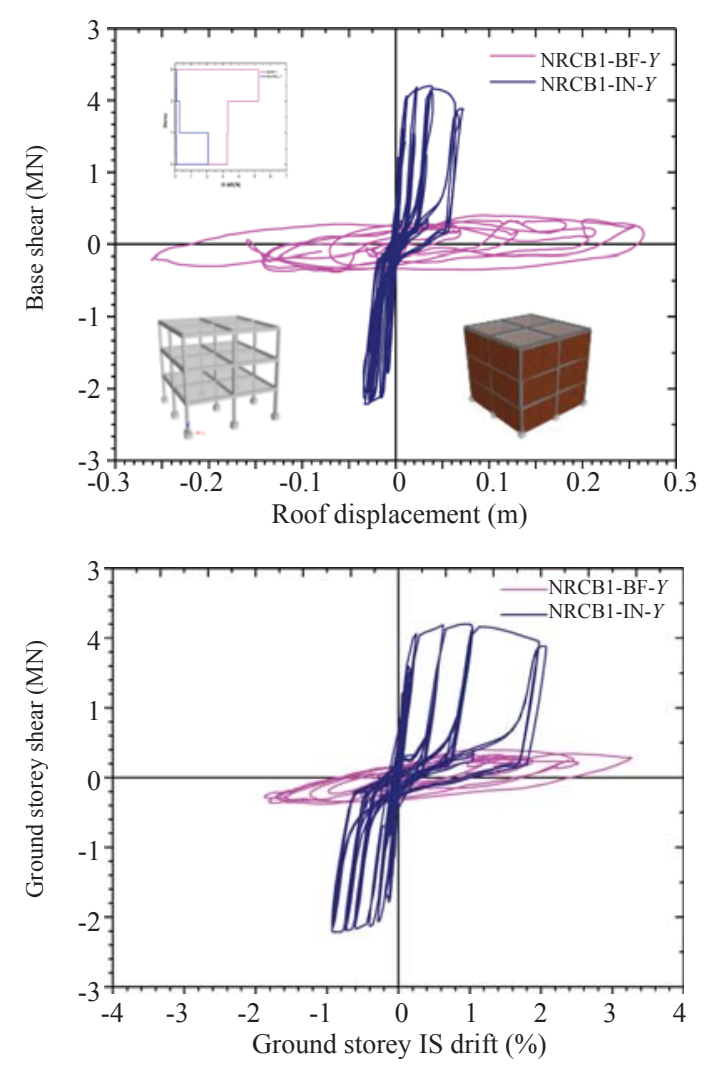

Fig. 19 Global base shear vs. roof displacement and corresponding first-storey shear vs. drift plot for building models NRCB1 and NRCB5 respectively levels for both bare frame and infill cases. In the global force displacement plot, deformations of a structure with a bare frame and with infill exhibit greater differences. Conversely, the differences are minimal in the groundstorey shear vs. ground-storey drift plot (see Fig. 19). Moreover, the infill accumulates all the forces in the ground storey. This can be seen from the IS drift profile and ground-storey shear-drift plots. The ground-storey shear-drift diagram for the structure with infill shows a rapid decrease in strength after reaching its maximum value.

\subsubsection{Rotation}

To study the effect of irregularity on seismic response of structures, one irregular and one regular building with and without infill are considered. The effect of infill is clearly apparent in the irregular building model. Due to the torsional effect on irregular building, the masonry infill wall accumulates all the earthquake forces in the ground storey of the building, resulting in greater rotation in the first floor (NRCB4). However, masonry infill significantly reduces the rotation in a regular structure (NRCB2). Results presented in Fig. 20 indicate that the introduction of masonry infill has both positive and negative effects. Masonry infill significantly reduced the rotation of the structure in NRCB2 (i.e., improves the seismic response of the structure). However, in NRCB4 the presence of infill significantly increases the floor rotation of the structure (i.e., infill can cause unexpected damage to the structure).
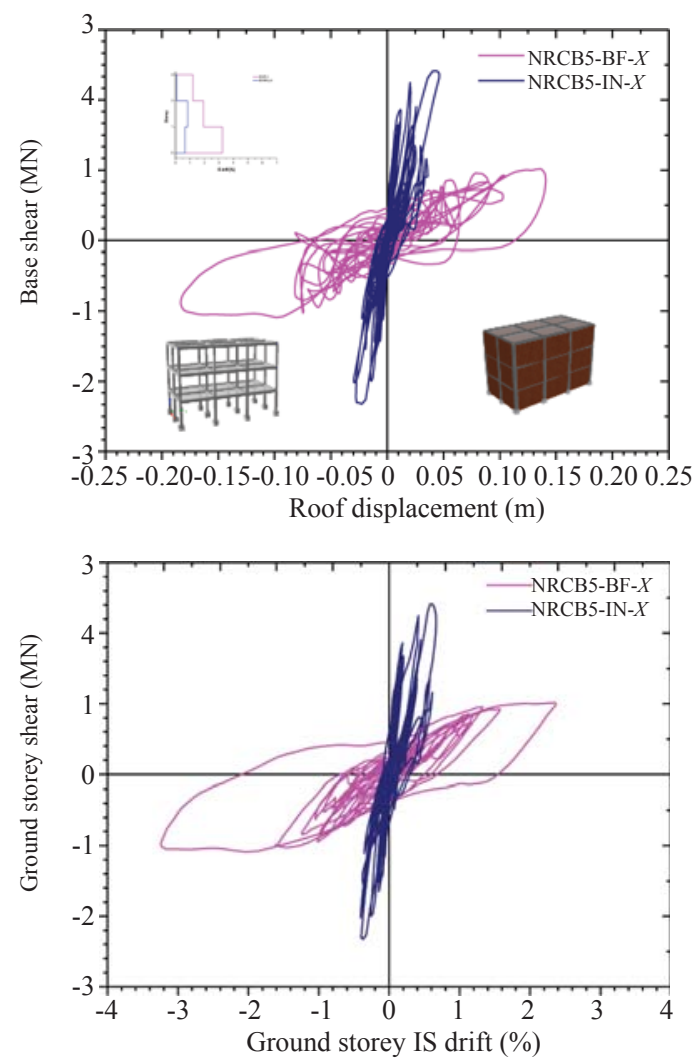


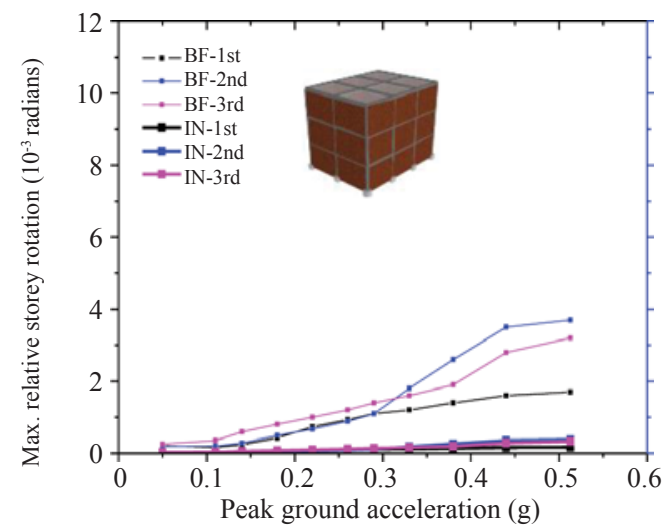

(a)

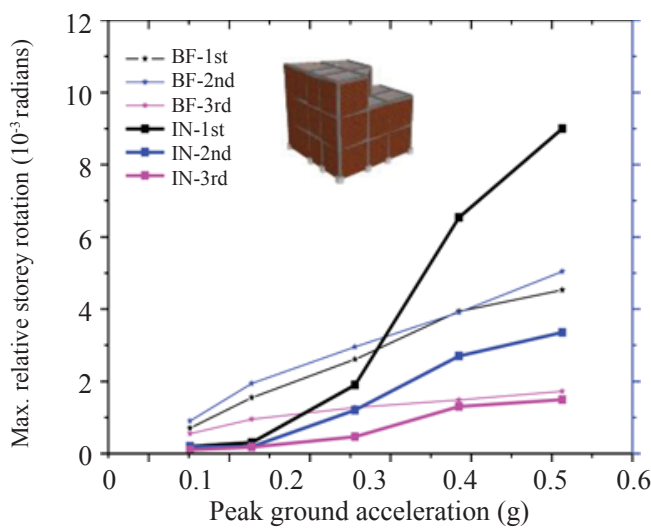

(b)

Fig. 20 Effect of masonry infill walls on rotation for: (a) NRCB2 and (b) NRCB4 buildings

\section{Influence of material properties on building response}

Reinforced concrete structures with masonry infill are used extensively in urban areas of Nepal. Masonry panels are usually built up after the frames and floor structures have been constructed. While designing the structures, structural engineers largely ignored the influence of masonry panels when selecting the structural configuration, assuming that these brick masonry panels are brittle elements compared with the frame. The design practices of neglecting the infill lead to inaccuracy in predicting the lateral strength, stiffness, and ductility of the structure. The varied material properties (such as compressive strength, tensile strength, modulus of elasticity) of infill masonry panels are responsible for large variations in the performance of structures (Pradhan, 2012; Pradhan et al., 2010; Buratti et al., 2010; Williams et al., 2009). Thus, in this study, the effect of material properties on the response of the infill masonry structure is addressed. For this, the diagonal compressive strength, modulus of elasticity and tensile strength of the brick masonry panel are selected as study parameters. Initially, variations of these parameters are set as the $25 \%$ and $50 \%$ levels based on a review of the available literature (D'Ambrisi et al., 2013; Rajeev and Tesfamariam, 2012; Schotanus et al., 2004).

\subsection{Parametric analysis}

In this section, the influence of the variation in material properties of the masonry infill, namely diagonal compressive strength $\left(f_{\mathrm{m}}\right)$, young's modulus of elasticity $\left(E_{\mathrm{m}}\right)$, and tensile strength $\left(f_{\mathrm{t}}\right)$, are studied. The results from the variation of each parameter can be expressed in terms of maximum roof displacement, maximum interstory drift (IS), and maximum base shear.

Results indicate that the effect of variation of the diagonal compressive strength on the structure is clearly apparent in all building models. The maximum interstorey drift (IS) is decreased by $34 \%$ and $64 \%$ when the diagonal compressive strength of masonry is increased by $25 \%$ and $50 \%$, respectively. For the same ratio of the increment of $f_{\mathrm{m}}$ value, the maximum displacement is decreased by $28 \%$ and $53 \%$, respectively. However, the maximum inter-storey drift is increased to $180 \%$, for the $25 \%$ reduction of diagonal compressive strength of masonry $\left(f_{\mathrm{m}}\right)$ panel. In short, a reduction in the diagonal compressive strength of brick masonry wall plays an important role in increasing the inter-storey drift in nonengineered buildings. When the reduction of $f_{\mathrm{m}}$ value is pushed to $50 \%$, numerical instabilities in the structures result. Furthermore, the variation in base shear is limited to $40 \%$ for all building models. Variations of the young's modulus of the masonry infill panels change the structural behavior to a certain extent for all the studied buildings. However, variation of the tensile strength does not have so much effect when compared with the other parameters. As indicated in Fig. 21, it can be concluded that the performance of structures is dominated by the diagonal compressive strength of the masonry infill panel. There is very minor fluctuation in the structural response due to variations in the young's modulus and tensile strength of the masonry panel.

\subsection{Effect on reduction of diagonal compressive strength on global response of structure}

Results obtained in Section 6.1 indicate that a reduction in the diagonal compressive strength of the infill masonry wall plays an important role in the seismic behavior of the structures. Therefore, non-linear dynamic analysis is further conducted with the nominal $\left(2.3 \mathrm{~N} / \mathrm{mm}^{2}\right)$, $25 \%$-reduced $\left(1.725 \mathrm{~N} / \mathrm{mm}^{2}\right)$ and $50 \%$ - reduced $\left(1.15 \mathrm{~N} / \mathrm{mm}^{2}\right)$ values of the diagonal compressive strength of a masonry panel with increasing peak ground accelerations. Figure 22 presents the influence of material properties on the response of non-engineered (NRCB2) (Fig. 22(a)) and engineered (NRCB3) (Fig. 22(b)) building models. In both of these building models, initially the masonry infill panel significantly improves the response of buildings by reducing the inter-storey drift. However, the maximum inter-storey drift value increased greatly at lower diagonal compressive strength of masonry. 

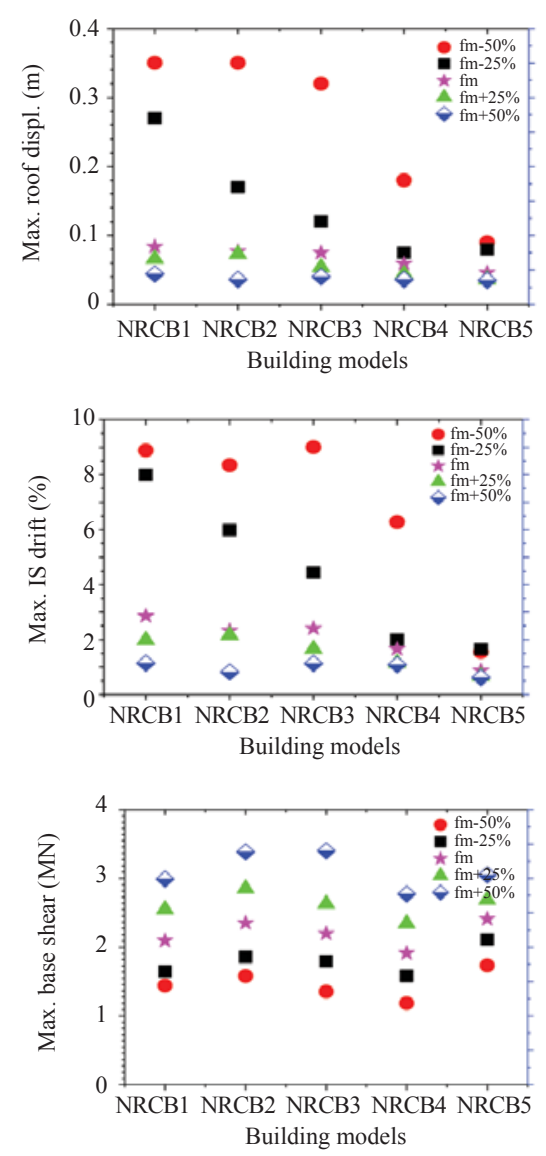

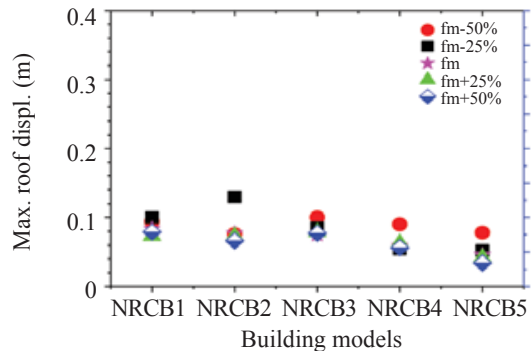

(a)

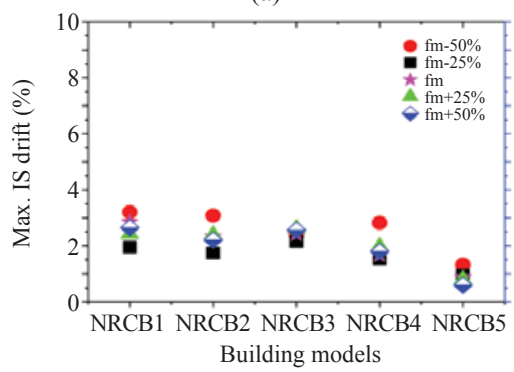

(b)

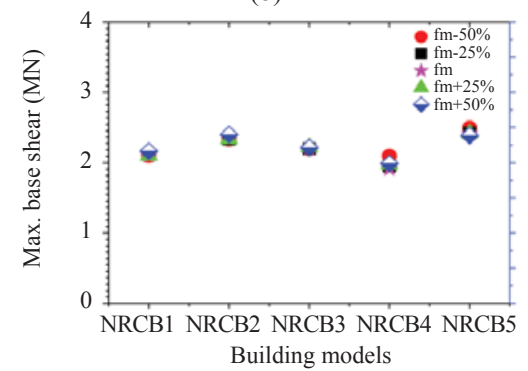

(c)
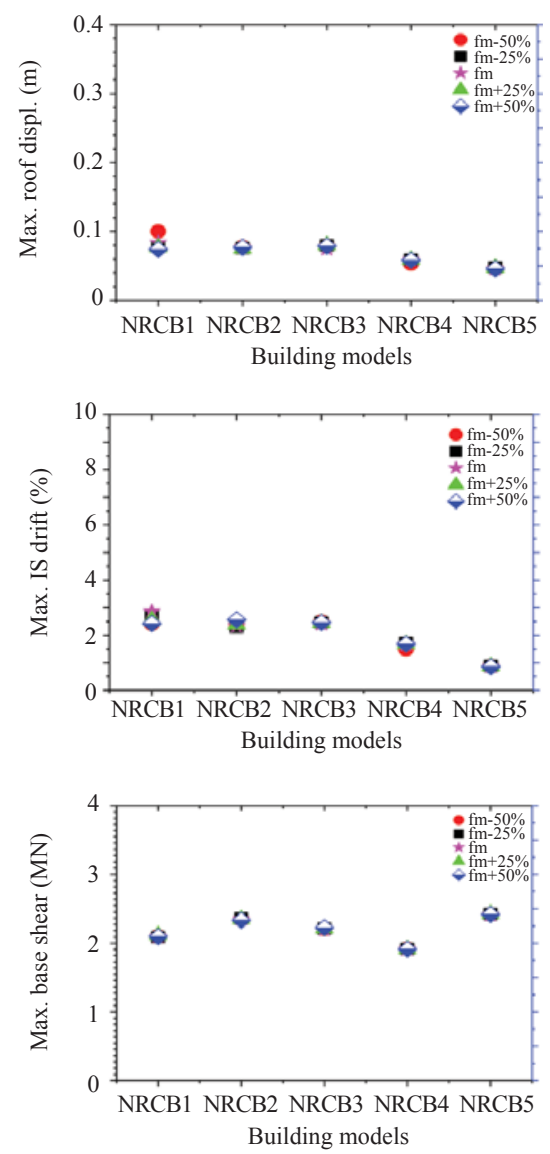

Fig. 21 Effect in variation of diagonal compressive stress $\left(f_{\mathrm{m}}\right)$, Young's modulus $\left(E_{\mathrm{m}}\right)$ and tensile stress $\left(f_{\mathrm{t}}\right)$ of masonry infill on: (a) max. roof displacement; (b) max. IS drift; and (c) max. base shear respectively
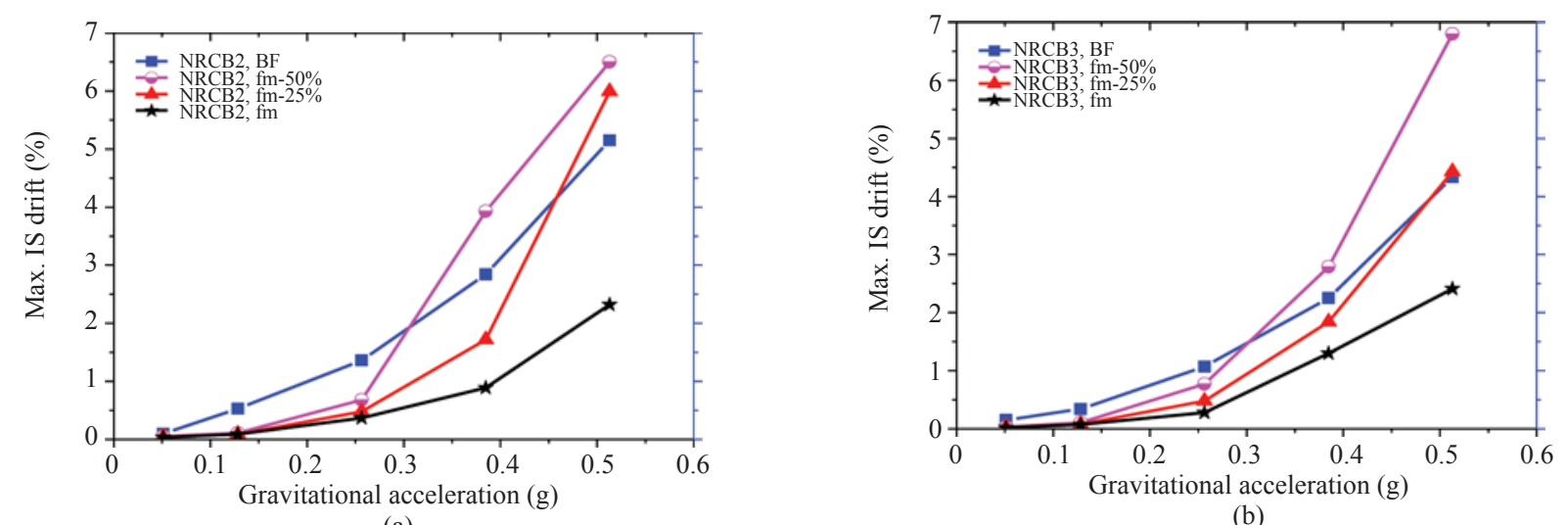

(b)

Fig. 22 Effect of reduction of diagonal compressive strength of masonry infill on seismic vulnerability of structures for: (a) NRCB2 and (b) NRCB3

Initially at lower ground motion, structures with both the normal and reduced material properties have similar behaviors up to $0.25 \mathrm{~g}$ PGA value. The behaviors of the structures divert with increasing ground motion values. This shows that a reduction in the diagonal compressive strength of materials leads to favorable result to a certain extent, but for stronger ground motions, it has a negative effect on structures. The excessive increase in the interstorey drift due to lower compressive strength may lead to failure of the structure as a result.

\subsection{Vulnerability effects on global behavior of structures}

In order to assess the seismic vulnerability of the buildings under study, results of the structures with and without masonry infill are compared with maximum drift demands and the basic performance objectives proposed by FEMA-356 (2000) and Ghobarah (2004). These proposed values have been used by several authors to assess the safety of RC buildings and they provide a guideline on acceptable performance of such structures. 
Figure 23 presents the vulnerability curves for the buildings, including drift limits for ductile momentresisting frame, non-ductile moment-resisting frame and moment-resisting frame with infills proposed by FEMA356 (2000) and Ghobarah (2004). It can be observed that the maximum displacement and maximum IS drift of non-engineered buildings appeared at $0.513 \mathrm{~g}$. The introduction of infill panels dramatically decreases the maximum displacement and corresponding IS drift in all structures. The effect is more pronounced in nonengineered buildings. For example, at $0.25 \mathrm{~g}$ PGA, the maximum roof displacement of the non-engineered building is more than $0.15 \mathrm{~m}$ whereas it is less than $0.10 \mathrm{~m}$ in the engineered and well designed structures. Similarly, for the same ground motion, the maximum IS drift in non-engineered structures is greater than $2.5 \%$ whereas it is limited to $1 \%$ in the remaining structures. As expected, infill panels greatly increase the strength and stiffness of the structures. The rate of increase of the maximum base shear is clearly apparent up to $0.38 \mathrm{~g}$ PGA. This indicates that infill works well within a certain level of ground motion.

Seismic safety assessments of the bare frame and masonry infill structures are performed based on standard guidelines discussed in Subsection 2.4 and presented in Table 1. Comparing the maximum storey drift demands for bare frame structures within the limit states, it is observed that non-engineered (NRCB1, NRCB2) buildings are under the minimum drift limit level. However, engineered (NRCB3 and NRCB4) buildings are safe within the life safety level. The well designed structures (NRCB5) are quite safe for all performance levels. However, in all the studied building models, the introduction of masonry infill panels drastically modifies the performance of all building structures.

\section{Conclusions}

Masonry infill panels have a complex behavior due to their unique material properties and to the interaction with the surrounding frames. Therefore, the response of such structures is highly complex and depends on many factors ranging from material properties to workmanship. This study presents an extensive case study regarding the analysis of existing RC buildings in Nepal. The effect of masonry infill panels on the response of the structure was quantified by comparison with a bare frame through non-linear analysis. Similarly, sensitivity analyses of infill masonry structures were performed by varying the diagonal compressive strength, modulus of elasticity and tensile strength of the infill panels. Moreover, seismic safety assessment was also performed using standard guidelines.

The results can be summarized as follows:

- The seismic performance of a structure is

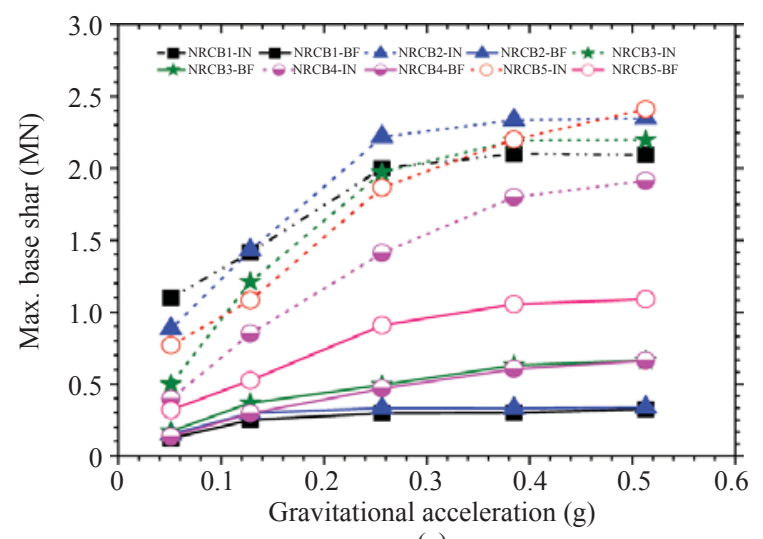

(a)

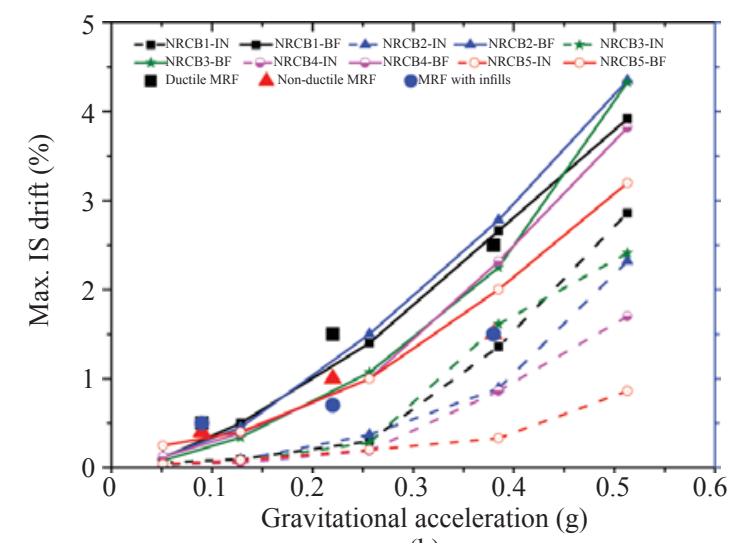

(b)

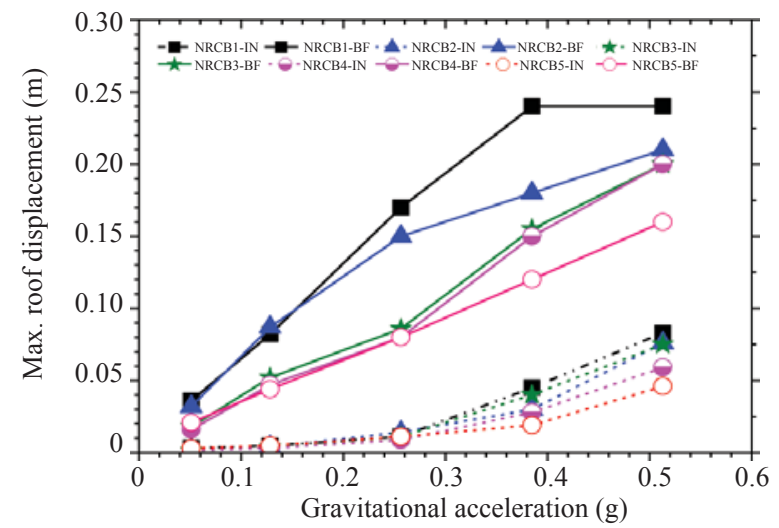

(c)

Fig. 23 Vulnerability curves of: (a) max. roof displacement; (b) max. IS drift; and (c) max. base shear for structures with and without masonry infill wall 
greatly improved by the introduction of infill walls. The maximum roof displacement predicted by the infill model is about $80 \%$ of that for the bare frame model.

- The introduction of infill wall reduces considerably the inter-storey drift, by more than $50 \%$ of the bare frame structures. Structures with infill walls have well-distributed inter-storey drift profiles. Hence, ignoring the effect of the masonry infill would lead to under-estimation of the seismic performance of structures.

- The introduction of infill panel modifies the frame action of a moment-resisting frame structure, adding a combined frame and truss action between frame and masonry infill wall. Hence, the infill model has more axial force in columns than the bare frame.

- The presence of infill panels alters the structural response to horizontal forces in both $X$ and $Y$ directions. Engineered buildings have an increased stiffness (4-12) times in the $X$ direction and 10 times in the $Y$ direction. These values become more than 20 times for nonengineered building structures. However, in the well designed structure, the enhanced stiffness is limited to 12 and 7.5 times in the $X$ and $Y$ directions, respectively. With regard to strength, it can be observed that masonry infill is (3-4.5), (6.3-7.7) and (2.4-2.5) times higher in strength than bare frame in engineered, non-engineered and well designed structures, respectively.

- The introduction of infill panels significantly increases the stiffness of the structures resulting in a decrease in the natural vibration periods of the buildings.

- In bare frame structures, uniform, adaptive, and triangular load patterns represent an upper, intermediate, and lower boundary, respectively, of the capacity curve in all the analysis cases. However, corresponding results are somewhat diverse for structures with masonry infill; the same loading case may lead to dissimilar capacity curves.

- Parametric analysis based on variation in material properties, viz., compressive strength, modulus of elasticity and tensile strength of masonry infill, indicate that the diagonal compressive strength of masonry has a significant influence on the performance of structures as compared with other parameters.

- Comparing the maximum storey drift demands for bare frame structures within the limit states, it is observed that non-engineered building structures are under the minimal drift limit level. Engineered buildings are safe within the life safety level, and the well designed structure behave quite safely at all performance levels. In most of the cases, infill increases the safety level of the structures within a certain range of ground motion.

- Due to the torsional effect on irregular structures, masonry infill panels accumulate all the earthquake forces on the first floor of the structures, resulting in higher rotation of the first floor. However, infill panels significantly reduce the rotation in regular structures. Hence, masonry infill panels can significantly improve the seismic response of a structure or they can cause unexpected damage; the influence of masonry infill on the seismic performance of structures should not be ignored.

- A reduction in the diagonal compressive strength of materials has favorable results within a certain level of ground motion. However, if strength is further reduced, adverse effects may result for higher magnitude of shaking. This is exactly the case of softstories when infill cannot take any more loads. Thus, the choice of the diagonal compressive strength of the masonry infill panel plays a very important role in the response of a structure.

\section{Acknowledgement}

This research investigation is supported by the Eurasian University Network for International Cooperation in Earthquake (EU-NICE), through fellowship for $\mathrm{PhD}$ research of the first Author. This support is gratefully acknowledged.

\section{References}

Bell DK and Davidson BJ (2001), "Evaluation of Earthquake Risk Buildings with Masonry Infill Panels," Technical Conference, Future Directions: A Vision for Earthquake Engineering in New Zealand, New Zealand Society for Earthquake Engineering Taupo, New Zealand.

Bothara J and Hiçyılmaz K (2008), "General Observations of Building Behaviour during the 8th October 2005 Pakistan Earthquake," Bulletin of the New Zealand Society for Earthquake Engineering, 41(4): 209-233.

Buratti N, Ferracuti B and Savoia M (2010), "Response Surface with Random Factors for Seismic Fragility of Concrete Frames," Structural Safety, 32(1): 42-51.

CEN (2003), Eurocode 8: Design of Structures for Earthquake Resistance - Part 1-3: Strengthening and Repair of Buildings - European prEN 1998-1-3, European Committee for Standardization, Brussels, Belgium.

Chaulagain H, Rodrigues H, Spacone E and Varum H (2014), "Study on Design Procedures of Reinforced Concrete Buildings in Nepal and Its Impact on Seismic Safety," Advances in Structural Engineering 17(10): 1419-1442.

Crisafulli FJ (1997), "Seismic Behavior of Reinforced Concrete Structures with Masonry Infills," PhD Thesis, University of Canterbury, New Zealand.

Dhanesekar M and Page AW (1986), "The Influence of Brick Masonry Infill Properties on the Behavior of Infill Frames," Proceedings of the Institution of Civil Engineers, 81: 593-603.

Dogangun A (2004), "Performance of Reinforced 
Concrete Buildings during the May 1, 2003 Bingo Earthquake in Turkey," Journal of Engineering Structures, 26(6): 841-856.

Dolšek M and Fajfar P (2005), "Simplified Non-linear Seismic Analysis of Infilled Reinforced Concrete Frames," Earthquake Engineering and Structural Dynamic, 34(1): 49-66.

Elnashai AS and Elghazouli AY (1993), "Performance of Composite Steel/concrete Members under Earthquake Loading, Part I: Analytical Model," Earthquake Engineering and Structural Dynamics, 22(4): 315-345.

FEMA 273 (1997), NEHRP Guidelines for the Seismic Rehabilitation of Buildings, Federal Emergency Management Agency, Washington, D.C.

FEMA 306 (1997), Evaluation of Earthquake Damaged Concrete and Masonry Wall Buildings, Basic Procedures Manual, Federal Emergency Management Agency, Washington, D.C.

FEMA 307 (1999), Evaluation of Earthquake Damaged Concrete and Masonry Wall Buildings, Technical Resources, Federal Emergency Management Agency, Washington, D.C.

FEMA 356 (2000), Pre-standard and Commentary for the Seismic Rehabilitation of Buildings, Federal Emergency Management Agency, Washington, D.C.

Filippou FC, Popov EP and Bertero VV (1983), "Effects of Bond Deterioration on Hysteretic Behaviour of Reinforced Concrete Joints," Report EERC 83-19, Earthquake Engineering Research Center, University of California, Berkeley.

Freeman SA (1977), "Racking Tests of High Rise Building Partitions," Journal of Structural Division, ASCE, 103(8): 1673-1685.

Ghobarah A (2004), "On Drift Limits Associated with Different Damage Levels," Proceedings of the International Workshop, Bled, Slovenia, 28: 321-332.

IS 13920:1993 (1993), Indian Standard Ductile Detailing of Reinforced Concrete Structures Subjected to Seismic Force, Bureau of Indian Standards, ManakBhavan, 9 Bahadur Shah Zafar Marg, New Delhi.

IS 1893 (Part1):2002 (2002), Indian Standard Criteria for Earthquake Resistant Design of Structures, Bureau of Indian Standards, ManakBhavan, 9 Bahadur Shah ZafarMarg, New Delhi.

IS 456 (2000), Plain and Reinforced Concrete Code of Practice, Bureau of Indian Standards, ManakBhavan, 9 Bahadur Shah ZafarMarg, New Delhi.

IS 875 (2003), Code of Practice for Design Loads for Buildings and Structures, Bureau of Indian Standards, ManakBhavan, 9 Bahadur Shah ZafarMarg, New Delhi.

JICA (2002), The Study on Earthquake Disaster Mitigation in the Kathmandu Valley Kingdom of Nepal, Japan International Cooperation Agency (JICA) and Ministry of Home Affairs, His Majesty's Government of Nepal.Vol: I, 110+.
Madas P and Elnashai AS (1992), "A New Passive Confinement Model for the Analysis of Concrete Structures Subjected to Cyclic and Transient Dynamic Loading," Earthquake Engineering and Structural Dynamic, 21(5): 409-431.

Magenes G and Pampanin S (2004), "Seismic Response of Gravity-load Design Frames with Masonry Infills," 13th World Conference on Earthquake Engineering, Vancouver, B.C., Canada.

Mainstone RJ (1971), "On the Stiffnesses and Strengths of Infilled Frames," Proceedings of the Institution of Civil Engineers, Supplement (IV), No. 73605: 57-90.

Mander JB, Priestley MJN and Park R (1988), "Theoretical Stress-strain Model for Confined Concrete," Journal of Structural Engineering, 114 (8): 1804-1826.

Martinez-Rueda JE (1997), "Energy Dissipation Devices for Seismic Upgrading of RC Structures," PhD Thesis, Imperial College, University of London, London, UK.

Menegotto M and Pinto PE (1973), "Method of Analysis for Cyclically Loaded R.C. Plane Frames Including Changes in Geometry and Non-elastic Behaviour of Elements under Combined Normal Force and Bending," Symposium on the Resistance and Ultimate Deformability of Structures Acted on by Well Defined Repeated Loads, International Association for Bridge and Structural Engineering, Zurich, Switzerland, pp. 15-22.

NBC 205 (1994), Mandatory Rules of Thumb, Reinforced Concrete Buildings without Masonry Infill, HMG/ Ministry of Housing and Physical Planning, Department of Building, Kathmandu, Nepal.

Pandey MR, Chitrakara GR, Kafle B, Sapkota SN, Rajaure S and Gautam UP (2002), Seismic Hazard Map of Nepal, National Seismological Centre, Kathmandu Nepal.

Parajuli H (2009), "Dynamic Analyses of Low Strength Masonry Houses Based on Site Specific Earthquake Ground Motions," PhD Thesis, Department of Urban Management, Graduate School of Engineering, Kyoto University, Japan.

Parajuli H, Kiyono J, Ono Y and Tsutsumiuchi T (2008), "Design Earthquake Ground Motions from Probabilistic Response Spectra: Case Study of Nepal," Journal of Japan Association for Earthquake Engineering, 8(4):

Paulay T and Priestley M (1992), Seismic Design of Reinforced Concrete and Masonry Buildings, John Wiley \& Sons, Inc., New York.

Pinho R and Elnashai AS (2000), "Dynamic Collapse Testing of a Full-scale Four Storey RC Frame," ISET Journal of Earthquake Engineering, Special Issue on Experimental Techniques, 37(4): 143-164.

Pradhan P (2012), "Equivalent Strut Width for Partial Infilled Frames," Journal of Civil Engineering Research, 2(5): 42-48.

Pradhan P, Murty CVR, Hoiseth K and Aryal M (2010), "Nonlinear Simulation of Stress-strain Curve of Infill 
Materials Using PLP fit Model," Journal of the Institute of Engineering, 7(1): 1-12.

Rajeev P and Tesfamariam S (2012), "Seismic Fragilities for Reinforced Concrete Buildings with Consideration of Irregularities," Structural Safety, 39(1): 1-13.

Rodrigues H, Varum H, Arêde A and Costa A (2011), "ComParison of Different Modelling Strategies for the RepResentation of Nonlinear Response of RC Columns Subjected to Biaxial Loading," International Conference on Recent Advances in Nonlinear Models - Structural Concrete Applications, CoRAN 2011, pp. 339-353, ISBN 978-972-96524-7-9, Coimbra, Portugal.

Rodrigues H, Varum H and Costa A (2010), "Simplified Macro-model for Infill Masonry Panels," Journal of Earthquake Engineering, 14(3): 390-416.

Schotanus M, Franchin P, Lupoi A and Pinto P (2004), "Seismic Fragility Analysis of 3D Structures," Structural Safety, 26(4): 421-441.

SeismoStruct (2006), A Computer Program for Static and Dynamic Nonlinear Analysis of Framed Structure [online], Available from URL: http//www.seismosoft. com.

Smyrou E, Blandon C, Antoniou S, Pinho R and Crisafulli F (2011), "Implementation and Verification of a Masonry Panel Model for Nonlinear Dynamic Analysis of Infilled RC Frames," Bulletin of Earthquake Engineering, 9(6): 1519-34.

UNDP (1994), Seismic Hazard Mapping and Risk Assessment for Nepal, His Majesty's Government of Nepal, Ministry of Housing and Physical Planning, UNDP/UNCHS (Habitat) SubprojectNEP/88/054/21.03. Varum H (2003), "Seismic Assessment, Strengthening and Repair of Existing Buildings," PhD Thesis, Department of Civil Engineering, University of Aveiro.

Vincente R, Rodrigues H, Varum H, Costa A and Silva J (2012), "Performance of Masonry Enclosure Walls: Lessons Learned from Recent Earthquakes," Earthquake Engineering and Engineering Vibration, 11(1): 23-34.

Williams R, Gardoni P and Bracci J (2009), "Decision Analysis for Seismic Retrofit of Structures," Structural Safety, 31(2): 188-196. 